NBER WORKING PAPER SERIES

\title{
EVIDENCE FOR THE EFFECT OF MONITORING COSTS ON FOREIGN DIRECT INVESTMENT
}

\author{
Bruce A. Blonigen \\ Anca D. Cristea \\ Donghyun Lee \\ Working Paper 25933 \\ http://www.nber.org/papers/w25933 \\ NATIONAL BUREAU OF ECONOMIC RESEARCH \\ 1050 Massachusetts Avenue \\ Cambridge, MA 02138 \\ June 2019
}

We thank Ron Davies, Nick Sly, and participants of seminars at the Baruch College and the University of Oregon for helpful comments. Any remaining errors or omissions are our own. The views expressed herein are those of the authors and do not necessarily reflect the views of the National Bureau of Economic Research.

NBER working papers are circulated for discussion and comment purposes. They have not been peer-reviewed or been subject to the review by the NBER Board of Directors that accompanies official NBER publications.

(C) 2019 by Bruce A. Blonigen, Anca D. Cristea, and Donghyun Lee. All rights reserved. Short sections of text, not to exceed two paragraphs, may be quoted without explicit permission provided that full credit, including $(\odot$ notice, is given to the source. 
Evidence for the Effect of Monitoring Costs on Foreign Direct Investment

Bruce A. Blonigen, Anca D. Cristea, and Donghyun Lee

NBER Working Paper No. 25933

June 2019

JEL No. D22,F21,F23,G34,L22

\begin{abstract}
$\underline{\text { ABSTRACT }}$
A proposed reason for the significant inverse relationship between distance (both physical and cultural) and foreign direct investment is the increased costs for a parent firm to monitor an affiliate when there is greater distance between them. We provide the first direct test of this hypothesis using $\mathrm{O}^{*} \mathrm{NET}$ data on occupational skills to construct industry-level measures of the importance of monitoring-related skills. We then exploit this cross-industry variation to examine whether physical and cultural distances have a greater impact on cross-border M\&A in industries where monitoring-related skills are more important. Using data on worldwide cross-border M\&A activity from 1985 through 2014, we find significant evidence for the effect of monitoring costs on cross-border M\&A activity. We also show that the relatively low importance of monitoringrelated costs in manufacturing industries compared to those in other sectors is an important factor in explaining why cross-border M\&A in manufacturing is so large despite its relatively small share of the modern economy.
\end{abstract}

Bruce A. Blonigen

Department of Economics

1285 University of Oregon

Eugene, OR 97403-1285

and NBER

bruceb@uoregon.edu

Anca D. Cristea

Department of Economics

1285 University of Oregon

Eugene, OR 97403-1285

cristea@uoregon.edu
Donghyun Lee

1301 College Avenue

University of Mary Washington

Fredericksburg, VA 22401

dlee6@umw.edu 


\section{INTRODUCTION}

The growth of world foreign direct investment (FDI) over the past few decades has been rapid. In accordance with this, there has been a significant research effort to explore the determinants (and frictions) that shape worldwide FDI patterns. As with international trade and other international transactions, gravity variables are significant explanatory variables for bilateral FDI flows and stocks. While it makes sense that country size measures should be positively correlated with respect to any international transaction one considers, the source of the inverse correlation with distance is less obvious. The common explanation for the inverse correlation between distance and international trade is transport costs. But this is an unlikely explanation for the inverse correlation of distance with FDI unless most firms engaging in FDI intend to trade a significant amount of inputs between the parent and its foreign affiliates. Also, most empirical studies of trade and FDI patterns include cultural distance measures such as language similarity, colonial relationships, etc., finding they are also signicant frictions for these international transactions.

A common explanation for the inverse correlation between FDI and physical and cultural distances is that they negatively affect the ease and efficiency of communication, coordination, and monitoring of activity across the firm's affiliates. This makes the prospect of FDI less profitable and therefore less likely. Head and Ries (2008) provide a theoretical model based on these principles for cross-border M\&A (a major type of FDI). They derive a gravity-like equation for explaining bilateral cross-country M\&A flows that predicts inverse relationships with physical and cultural distances due to the increased costs for the parent firm to monitor its foreign affiliate as these distances increase. 
While this hypothesis for the inverse relationship between FDI and physical and cultural distance is intuitive, there is no direct evidence of which we are aware that monitoring and communication costs are the source of these relationships. And there are other plausible reasons for these relationships besides monitoring costs. Physical distances are often associated with transport costs in the international trade literature, and so the evidence for the significance of physical distance could be because transport of intermediates between the parent and affiliate are substantial and costly with increased distance, not because monitoring is challenged by distance. Likewise, there are a number of reasons for why cultural distances might be deleterious to cross-border M\&A other than monitoring costs. For example, their main impact may be in making it difficult to find appropriate targets in a potential host country, not monitoring it once they have acquired a target. Understanding the mechanisms behind the inverse correlation between FDI and distance is thus vital for refining our knowledge of FDI and our ultimate ability to inform policy.

Besides Head and Ries (2008), other prior empirical analyses have also argued that monitoring and communication costs are important for FDI and is the mechanism behind a number of empirical relationships. These include several papers that find evidence that cross-country institutional and legal differences hinder FDI (e.g., Habib and Zurawicki (2002), Aizenmann and Spiegel (2006), Bénassy-Quéré, Coupet, and Mayer (2007), and Raimondi and Scoppola (2018)) and a paper by Stein and Daude (2007) finding that FDI is more prevalent in countries in the same (or proximate) time zones 
because it is easier to communicate during common business hours. ${ }^{1}$ Like Head and Ries (2008), these studies rely on cross-country differences for evidence consistent with their hypotheses. This approach suffers from the critique that other unobserved country-level differences may be driving these correlations which are otherwise unrelated to the postulated mechanism.

In contrast, this paper uses an identification method analogous to that of Rajan and Zingales (1998) to provide the first direct test of the monitoring-cost hypothesis. We develop a new cross-industry measure of the importance of monitoring and related skills for firms within industrial sectors and interact this sectoral data with cross-country measures of physical and cultural distances. If these bilateral country distances are hampering FDI due to monitoring costs, then we should see that they are especially harmful to industrial sectors where monitoring is more important. ${ }^{2}$

In order to implement this identification strategy within a theoretical framework, we extend the Head and Ries (2008) model of cross-border M\&A activity to incorporate sectoral heterogeneity, as their original model is only specified at the country level. We then use cross-border M\&A data from Thomson SDC Platinum database ranging from

\footnotetext{
${ }^{1}$ These papers are part of a growing literature that investigates the determinants of cross-border M\&A, including Rossi and Volpin (2004), Di Giovanni (2005) Head and Ries (2008), Hijzen et al. (2008), Erel et al. (2012), and Blonigen and Piger (2014). These studies generally find that gravity-type forces are important for cross-border M\&A and especially examine the role of various types of cross-border frictions, as well as financial and institutional frictions in the home and host country.

${ }^{2}$ Davies et al. (2018) use a similar strategy to look at the different question of whether FDI occurs more in the form of cross-border M\&A or greenfield investments. One of their hypotheses is that cross-border M\&A should be more frequent relative to greenfield when integration of the acquired target would be more difficult. They interact sectoral measures of input contractability and intangible assets with physical and cultural differences and find some evidence that cross-border FDI is affected more by physical and cultural distances in sectors where input contractibility and intangible assets are high. These measures are consistently available only for primarily manufacturing sectors. In contrast, our measure of monitoring costs can be consistently measured across all sectors in the economy allowing us to focus on much different questions in this paper, such as why cross-border M\&A is proportionately much higher in the manufacturing sector than non-manufacturing sectors.
} 
1985-2014 as our measure of FDI. There are two main reasons for this. First, the value of cross-border M\&A activity is typically double that of greenfield FDI, the other major form of FDI. (For example, see Table I.10 on p. 11 of UNCTAD, 2015). Thus, by conducting the empirical analysis with cross-border M\&A data, we are capturing a substantial portion of the worldwide FDI activity. Second, the cross-border M\&A data from SDC Platinum provide disaggregated information across all countries at the four-digit SIC level, a level of detail that other FDI data cannot provide even for the countries with the most comprehensive FDI data.

We use data from the Occupational Information Network ( $\left.0^{*} \mathrm{NET}\right)$ to measure the extent to which occupations require various skills and construct a measure of how important monitoring is in an industry. ${ }^{3}$ While the previous literature has used these data primarily to look at the routineness of tasks that workers may be asked to do, the dataset also contains information on the degree to which various occupations require such things as monitoring of others, interpersonal skills, and communication skills. These directly connect to the Head and Ries (2008) rationale for why physical and cultural distances are inversely correlated with FDI. Using data on the employment shares of occupations for each industry (also available from $0^{*} \mathrm{NET}$ ), we construct measures of the importance of these monitoring-related skills by industry and interact them with the measures of physical and cultural distance between bilateral country pairs so that we can examine whether there is direct causal evidence for the monitoring cost mechanism.

\footnotetext{
${ }^{3}$ These data are available online at: https://www.onetonline.org. We use O*NET's ranking of the relevance and level of various social skills which we explain further below.
} 
Our econometric results provide strong evidence in favor of monitoring costs as a source of reduced cross-border M\&A activity. We find that a standard deviation increase in the monitoring importance in an industry is associated with a decrease in M\&A activity of about $40 \%$ and this effect is statistically significant at the $1 \%$ level. Interestingly, we find that the majority of this effect is driven by the physical distances, not cultural distances, across countries. These results are robust to alternative measures of monitoring importance, as well as to different samples of countries and years.

With our establishment that monitoring costs are an important mechanism driving the negative impact of physical and cultural distances on cross-border M\&A, we next investigate whether these costs are also significant in explaining another important feature of cross-border M\&A activity -- a substantial share of global FDI is in manufacturing and undertaken primarily amongst developed countries, yet manufacturing accounts for a very small (and rapidly declining) share of activity in these same developed countries. ${ }^{4}$ Could it be that the disproportionately larger share of crossborder M\&A in manufacturing is because there is less monitoring of affiliates required in manufacturing than other sectors? The raw data are consistent with this hypothesis, as our constructed measures of the importance of monitoring-related skills for the wholesale, retail, and financial, insurance, and real estate sectors (FIRE) are three to four times larger than for the manufacturing sector. We also find strong evidence for this when applying our formal econometric analysis. On average, our estimates suggest that

\footnotetext{
${ }^{4}$ For example, in the US, over $45 \%$ of value added by foreign affiliates operating in the US was in manufacturing in 2012 (Calculated from Table 2.1 in Anderson, 2014). However, total value added by manufacturing sector in the US accounted for only about 12\% of real GDP in 2012 (Elrod et al., 2013, Table E). Likewise, almost $40 \%$ of value added in 2011 by US affiliates operating in foreign countries was in manufacturing (Calculated from Table 2.1 in Barefoot, 2013).
} 
cross-border M\&A activity would be about $40-50 \%$ higher in the non-manufacturing sectors if they required as little monitoring-related skills as in manufacuring. However, there is significant heterogeneity across the non-manufacturing sectors. If monitoring importance were as low as that required in manufacturing, the high-monitoring sectors of wholesale trade, retail trade, and finance, insurance, and real estate would see their cross-border M\&A activity approximately double according to our estimates. But there would be much smaller increases (around 5-10\%) in the Services, Construction, and Transportation, communications, and Utilities. ${ }^{5}$

The rest of the paper proceeds as follows. Sections 2 and 3 describe our $0 *$ NET measure of monitoring across industrial sectors and our data on cross-border M\&A activity, respectively. Section 4 derives an empirical specification from the Head and Ries (2008) model and describes our identification strategy. Section 5 provides our empirical results both for the evidence on the monitoring-cost effect on FDI and how much it explains the heterogeneous cross-border M\&A activity we see across industrial sectors. The final section concludes.

\section{OCCUPATIONAL DATA ON MONITORING-RELATED SKILLS}

A novel aspect of our analysis compared to the previous literature is the use of information from the Occupational Information Network $\left(0^{*} \mathrm{NET}\right)$ dataset in order to measure the skills that are likely connected with parent firms' monitoring of foreign

\footnotetext{
${ }^{5}$ We are aware of only one other study (Ramasamy and Yeung, 2010) that has examined differences in FDI across sectors. Unlike our study, Ramasamy and Yeung (2010) rely on annual time series data aggregated at the one-digit sector level, which is estimated by a reduced-form equation. Their focus is on host-country characteristics unlike our focus on frictions. They find that the same types of host-market characteristics generally affect FDI across all sectors, and that service FDI appears to follow manufacturing FDI over time.
} 
affiliates and whose use may be made more difficult by greater physical and/or cultural distance. $0^{*}$ NET ranks both the level and the importance of over a hundred various skills for over 950 different occupations in the United States. "Monitoring skills" are the ones we gather from $0^{*}$ NET that include four skills that are labeled, "Coordination," "Management of material resources," "Management of personnel," and "Monitoring." These are tasks that likely become more difficult as the affiliate becomes more remote from the parent, irrespective of any cultural or language differences. Head and Ries (2008) posit that cultural distance can affect monitoring and use proxies such as language differences and colonial relationships for the cultural distance that will affect monitoring costs. Following this, we also group a number of these $0^{*}$ NET social skills into categories we label "cultural skills" and "language skills." The cultural skills we consider are those labeled by $0^{*}$ NET as "Negotiation skills," "Persuasion," "Service orientation," and "Social perceptiveness." Language skills include those labeled by O*NET as "Active listening," "Instructing," "Reading comprehension," "Speaking," and "Writing." Appendix B provides the O*NET description of each of these thirteen skills across the three categories of monitoring skills, cultural skills and language skills, respectively.

O*NET ranks the relevance of each skill for each occupation along two dimensions: importance and level. Importance (ranked from 1 to 5) measures how essential the skill is for the occupation, whereas the level (ranked from 0 to 7) indicates how proficient one must be in that skill for the occupation. These need not be highly correlated. For example, writing skills may be important for an occupation (such as a 
parking citations officer) on a daily basis, but not required to be at the highest level of proficiency.

In order to construct measures of the relevance of these thirteen skills at the industry level, we undertake the following steps. First, we multiply the level and importance of each skill by occupation and rescale so that all values fall between 0 and 1 . We then use the Occupational Employment Statistics (OES) survey provided by the Bureau of Labor Statistics (BLS) on employment by 2-digit Standard Industrial Classification (SIC) sectors across Standard Occupational Codes (SOCs) for the year 2000 to determine the share of each occupation for each industry. ${ }^{6}$ Using these shares, we create a weighted average of the relevance of each skill for each industry.

A final refinement is that we construct these measures with respect to only the occupation codes that are likely to be important for monitoring and coordinating activity between the parent and the affiliate: Management (SOC 11), Business and Financial Operations (SOC 13), and Sales and Related Occupations (SOC 41). We think it is unlikely that monitoring at non-executive levels (e.g., a floor supervisor on a production line) is important for the coordination and communication needed between a parent company and its foreign affiliate.

In practice, we find that these thirteen skills are highly correlated across 2-digit SIC industries with no pairwise correlation lower than 0.92 between any of the thirteen skills. That is, industries where monitoring is important at management or executive level are also industries where language and cultural skills are important. We have tried

\footnotetext{
${ }^{6}$ BLS provides a crosswalk between 2010 SOC codes and 2000 SOC codes, which we use in order to merge the O*NET skills data with the occupational employment share data.
} 
a variety of alternative methods for constructing our skill variables that all yield very high pairwise correlations. Given this, we collapse all thirteen of our skill variables into one monitoring-related $0^{*}$ NET variable by taking a simple average. This simplifies our analysis in many ways and, as we show later, our results are robust to a variety of alternative ways to define and construct the $0^{*} \mathrm{NET}$ variable.

Table 1 provides descriptive statistics for our $0^{*}$ NET variable where higher values indicate a greater importance of monitoring-related skills. The mean value of the $0 *$ NET variable is 0.062 across our entire dataset with a standard deviation of 0.05 . So there is significant variation across this measure with the value of the variable ranging from a minimum of 0.012 to 0.239 .

There is also a clear pattern in the data that monitoring-related skills are significantly less important in manufacturing industries than non-manufacturing industries. ${ }^{7}$ The mean value of the $0^{*}$ NET variable for manufacturing sectors is 0.035 , which is less than half the average of non-manufacturing industries at 0.073 . As seen in the final rows of Table 1, non-manufacturing industries are also quite diverse in terms of the prominence of monitoring-related skills even at the 1-digit SIC level. Monitoringrelated skills are less prominent for mining than manufacturing, while retail, wholesale, and finance, insurance and real estate (FIRE) have relatively high mean values for the O*NET variable. Table 2 shows the highest ten and lowest ten 2-digit SIC sectors with respect to the prominence of monitoring-related skills. The top ten sectors are all in retail and FIRE, while the lowest ten sectors are in mining, transportation, and a few unique

\footnotetext{
${ }^{7}$ The non-manufacturing industries that we are considering in this paper are: mining (SIC 10-14), construction (SIC 15-17), transport, communication and utilities (SIC 40-49), wholesale trade (SIC 50-51), retail trade (SIC 52-59), finance, insurance and real estate (SIC 60-67) and services (SIC 70-89).
} 
personal services. As we will see in our empirical analysis, this variation is highly significant in explaining differences in FDI patterns across countries.

\section{CROSS-BORDER M\&A ACTIVITY}

Like many other prior papers on M\&A activity, we rely on the Thomson Reuters SDC Platinum M\&A database to examine patterns in cross-border M\&A activity. The database begins in 1985 and records all M\&A transactions across the world that are valued at $\$ 5$ million or higher. If the percentage of shares acquired by the acquiring firm is $10 \%$ or more, we consider this an acquisition. A limitation of the data is that it does not have information on the value of transactions for about half of the observations, as private firms do not have to report this information. As a result, we rely on counts of M\&A transactions. The empirical model we present and estimate below naturally explains counts of transactions.

The entire database from 1985 through 2014 has over 600,000 acquisitions where $10 \%$ or more of the target company is acquired. About one-quarter of these observations are M\&A transactions that are cross-border; i.e, the acquiring firm's headquarters are located in a different country than the target firm's headquarters. Due to data availability issues, we examine cross-border acquisitions between countries that are the top 50 target countries for M\&A activity. M\&A activity between these top 50 countries accounts for over $80 \%$ of all M\&A activity in the database, and 
cross-border activity between OECD countries represents around 60\% of all crossborder acquisitions. ${ }^{8}$

Using the data set, we create a dependent variable of the number of crossborder acquistions at the two-digit SIC industry level for all directional country pairs from the set of the top 50 target countries in the database and cumulate these over 5year intervals beginning with 1985-1989 and ending with 2010-2014. ${ }^{9}$ We also explore samples with only the OECD countries, which have more intense M\&A activity amongst them and account for a substantial share of overall cross-border M\&A activity.

Importantly, the database has information on the primary 4-digit SIC classification of the acquiring and target firms, allowing us to focus on sectoral patterns of cross-border acquisitions, including non-manufacturing ones. Because the O*NET data are only available at the 2-digit SIC level, we aggregate our M\&A data to this level as well. For our purposes, we classify the M\&A transactions according to the SIC of the target firm.

To get a sense of the variation in cross-border M\&A activity across industries, Table 3 looks at such activity across one-digit sectors for our full sample and the OECD sample. As mentioned in the introduction, the manufacturing sector accounts for nearly $40 \%$ of all cross-border M\&A activity and this is nearly identical across both the top 50 and OECD samples. Of the non-manufacturing sectors, services is the largest and accounts for about one-quarter of all cross-border M\&A activity. The next largest

\footnotetext{
${ }^{8}$ We rank M\&A activity in terms of the number of firms targeted in that country for a M\&A and define OECD membership as of January 1, 2000 - roughly the midpoint of our sample. Appendix A lists the OECD countries, as well as the additional countries that comprise the top 50 target countries in our full sample.

${ }^{9}$ We limit to the top 50 because M\&A activity begins to get sparse beyond this set and then includes countries where we cannot easily obtain data for some of our regressors.
} 
sectors are FIRE (11-12\%), transportation, communications, and utilities (8-9\%), and wholesale trade (6\%). The distribution of cross-border M\&A across one-digit sectors is strikingly similar across the two samples.

If cross-country distances matter less for manufacturing because these distances are related to monitoring costs and such costs are less important for manufacturing sectors, then we would expect that manufacturing will have a bigger share of cross-border M\&A than domestic M\&A. Table 4 shows the number of acquisitions in manufacturing and non-manufacturing for both domestic and crossborder M\&A activity across all our sample years and for various sample countries. A universal pattern across all our differing samples of countries is that manufacturing accounts for a significantly larger share of cross-border M\&A activity (column 6) than domestic M\&A activity (column 3). For example, in our two samples of countries (top 50 and OECD), manufacturing accounts for only about $27-28 \%$ of targets acquired by domestic acquirers, but 39\% of targets acquired by foreign firms (i.e, cross-border M\&A). Across all top 10 target countries, the share of manufacturing targets is also always larger in the cross-border activity than in the domestic activity. These numbers suggest that cross-border M\&A is relatively easier for manufacturing industries than non-manufacturing ones, and we next outline the empirical model we will use to more formally explore whether cross-border frictions are a key mechanism in these differences we see in the raw data. 


\section{MODEL AND EMPIRICAL SPECIFICATION}

The Head and Ries (2008) model views cross-border M\&A as an international market for corporate control of productive assets, where the headquarters' monitoring cost of a (potential) subsidiary plays a key role in the cross-border M\&A decision. Frictional costs associated with cross-border M\&A stem from this monitoring cost because it is assumed that monitoring costs increase as the geographic or cultural distance between the home and host countries increases. Our strategy is to test this monitoring-cost mechanism using cross-sectoral variation in monitoring costs. In order to do so we must first extend the Head and Ries (2008) model to accommodate sectorspecific frictional costs.

The Head and Ries model is motivated by a simple inspection game, which is played between the headquarters (HQ) and its subsidiary. Without monitoring by the $\mathrm{HQ}$, the manager of the subsidiary lacks incentives to exert effort to maximize the value of the subsidiary. Monitoring requires costs that are increasing in distance (both cultural and geographic) between the HQ and its subsidiary. The subsidiary (manager) chooses whether to work or shirk. Gross profit depends on the contributions of the HQ and the subsidiary, which are denoted by $a$ and $b$, respectively. The HQ always adds $a$, whereas the subsidiary adds $b$ if it chooses to exert effort. The HQ simultaneously chooses whether to trust subsidiary or monitor and verify for a cost of $c$ that the subsidiary has worked. HQ pays $w$ to the subsidiary, unless monitoring reveals that the subsidiary is shirking, in which case the subsidiary gets zero. Working generates gross output of $a+b$, but the subsidary incurs effort costs of $e$. Head and Ries (2008) make parameter 
assumptions that $b>w>e>c>0$, and then solve for a mixed strategy Nash equilibrium of the inspection game, which yields the following expression for the value of the subsidiary:

$$
v=a+b-2 \sqrt{b c}
$$

As can be seen from equation (1), higher verification costs $(c)$ lower the value of the subsidiary to HQs. Head and Ries (2008) postulate the costs of monitoring (c) as an increasing function of $\mathbf{D}_{i j}$, which is a vector of geographic and cultural distances between the parent country $i$ and the host country $j$, and further specify the functional form of the costs related to these remoteness measures as $c_{i j}=\left(\frac{\mathbf{D}_{i j} \boldsymbol{\delta}}{2}\right)^{2}$, where $\boldsymbol{\delta}$ is a vector of parameters that weight the distance measures. Substituting into equation (1), the value of an acquisition between country $i$ and $j$ as:

$$
v_{i j}=a+b-\sqrt{b} \frac{\mathbf{D}_{i j} \boldsymbol{\delta}}{2}
$$

As discussed more below, country-level cultural and physical distances may affect cross-border M\&A in a number of other non-trivial ways than through monitoring costs, including transport of goods and the initial search for acquisition targets. Thus, the strong evidence for the role of these cross-border frictions in Head and Ries (2008) does not identify if monitoring costs are the mechanism. Our test relies on sectoral variation across measures of monitoring intensity, so we begin our extension of their model with the simple assumption that monitoring costs also vary by sector $(k), c_{i j k}=\left(\frac{\mathbf{D}_{i j k} \boldsymbol{\delta}}{2}\right)^{2}$, which then modifies equation (2) as follows:

$$
v_{i j k}=a+b-\sqrt{b} \frac{\mathbf{D}_{i j k} \boldsymbol{\delta}}{2}
$$

In order to derive an estimating equation from (3), we continue to follow Head and Ries (2008), while extending their model to account for sectoral variation. We 
assume that the HQ with the highest expected payoff (i.e., $v$ ) makes the highest bid and wins the auction for control of a subsidiary. Let $\pi_{i j k}$ denote the probability that a HQ from country $i$ takes control of a randomly drawn target in country $j$ in industry $k$. Also, let $K_{j k}$ denote the asset value of the entire stock of targets in the host country $j$ in industry $k$. Then we can represent the expected bilateral FDI stocks as follows,

$$
E\left[F_{i j k}\right]=\pi_{i j k} K_{j k}
$$

We follow Head and Ries (2008) in specifying $\pi_{i j k}$, assume that country $i$ has $m_{i}$ headquarters, each of which have different valuations for a given target in country $j$. Heterogeneity in the valuations is introduced through the HQ value-added term $a$. We assume that the cumulative density of $a$ takes the Gumbel (type-I extreme value): $\exp (-\exp (-(x-\mu) / \sigma))$, where $\mu$ is the location parameter and $\sigma$ is the shape parameter. Using the results of Anderson, de Palma, and Thisse (1992, p. 39), it can then be shown that $\pi_{i j k}$ is given by the multinomial logit formula:

$$
\pi_{i j k}=\frac{\exp \left[\frac{\mu_{i}}{\sigma}+\ln \left(m_{i}\right)-\frac{\sqrt{b}}{\sigma} \mathbf{D}_{i j k} \boldsymbol{\delta}\right]}{\sum_{\zeta} \exp \left[\frac{\mu_{\zeta}}{\sigma}+\ln \left(m_{\zeta}\right)-\frac{\sqrt{b}}{\sigma} \mathbf{D}_{\zeta j k} \boldsymbol{\delta}\right]}
$$

Substituting (4) into (3), we can express expected bilateral FDI stocks as

$$
\mathrm{E}\left[F_{i j k}\right]=\frac{m_{i} \exp \left[\frac{\mu_{i}}{\sigma}-\frac{\sqrt{b}}{\sigma} \mathbf{D}_{i j k} \boldsymbol{\delta}\right]}{\sum_{\zeta} m_{\zeta} \exp \left[\frac{\mu_{\zeta}}{\sigma}-\frac{\sqrt{b}}{\sigma} \mathbf{D}_{\zeta j k} \boldsymbol{\delta}\right]} K_{j k}
$$

In order to obtain an estimating equation, we first define $\boldsymbol{\theta} \equiv\left(\frac{\sqrt{b}}{\sigma}\right) \boldsymbol{\delta}$, which determines the FDI-impeding effect of the frictions that increase monitoring costs. Also, $E\left[F_{i j k}\right]$ depends only on the shares of HQs in each country, so we introduce $s_{i}^{m} \equiv \frac{m_{i}}{\sum_{\zeta} m_{\zeta}}$ to represent a country's share of the world's bidders. And finally, we define 
$B_{j k} \equiv \sum_{\zeta} s_{\zeta}^{m} \exp \left[\frac{\mu_{\zeta}}{\sigma}-\mathbf{D}_{\zeta j k} \boldsymbol{\theta}\right]$ as the "bid competition" for targets in country $j$ in industry $k$. Re-writing equation (5) in terms of these variables yields:

$$
E\left[F_{i j k}\right]=\exp \left[\frac{\mu_{i}}{\sigma}-\boldsymbol{D}_{i j k} \boldsymbol{\theta}\right] s_{i}^{m} K_{j k} B_{j k}^{-1}
$$

Equation (6) now resembles the gravity equation where expected bilateral stocks are increasing in size variables connected to the origin and destination $\left(s_{i}^{m}\right.$ and $\left.K_{j k}\right)$ and decreasing in measures of bilateral distance. Higher bid competition in country $j$ in industry $k$ (i.e., $B_{j k}$ ) implies that a higher fraction of assets in $j$ in industry $k$ will be taken by rivals from other countries, thereby reducing the expected bilateral stocks of HQs from country $i$.

Standard industrial classifications used to define $k$ in our data vary for both market structure reasons and artificial classification reasons. For example, manufacturing has many narrowly-defined industry classifications each composed of a relatively small number of establishments, whereas services tends to have more broadlydefined industry classifications with many firms. This matters because it directly affects the number of potential targets $(\mathrm{K})$ and potential bidders (B) across sectors in a systematic way. To account for this we introduce a $k$-specific scaling factor that allows us to rewrite $K_{j k} B_{j k}^{-1}$ as $\lambda_{k} K_{j} B_{j}^{-1}$. While this assumes a common industrial structure across our economies with respect to the relative number of firms in each sector, it allows us to extend Head and Ries (2008) in a tractable way to the sectoral level given available data.

Further re-arrangement of equation (6) gives us some insight into how the parameters of the model can be estimated: 


$$
E\left[F_{i j k}\right]=\exp \left[\frac{\mu_{i}}{\sigma}+\ln s_{i}^{m}+\ln K_{j}-\ln B_{j}+\ln \lambda_{k}-\mathbf{D}_{i j k} \boldsymbol{\theta}\right]
$$

Equation (7) shows that bilateral FDI can be separated into an origin $i$-specific term relating to its share of the world's HQs $\left(\ln s_{i}^{m}\right)$ and their mean ability $\left(\frac{\mu_{i}}{\sigma}\right)$, and a destination $j$-specific term relating to the share of target assets $\left(\ln K_{j}\right.$ ) and the competing set of bidders $\left(\ln B_{j}\right)$. We will denote $O_{i} \equiv \frac{\mu_{i}}{\sigma}+\ln s_{i}^{m}$ as the outward direct investment effect for origin $i, I_{j} \equiv \ln K_{j}-\ln B_{j}$ as the inward direct investment effect for destination $j$, and $S_{k} \equiv \ln \lambda_{k}$ as the sectoral effect. Substituting these terms, we obtain the following expression for expected bilateral FDI stocks:

$$
E\left[F_{i j k}\right]=\exp \left[O_{i}+I_{j}+S_{k}-\mathbf{D}_{i j k} \boldsymbol{\theta}\right]
$$

In order to move from the expected values determined in the theory to the actual values of FDI recorded in the data set, we define $\eta_{i j k} \equiv \frac{F_{i j k}}{E\left[F_{i j k}\right]}$ as the ratio of actual to expected bilateral FDI stocks. Using equation (8),

$$
F_{i j k}=E\left[F_{i j k}\right] \eta_{i j k}=\exp \left[O_{i}+I_{j}+S_{k}-\mathbf{D}_{i j k} \boldsymbol{\theta}\right] \eta_{i j k}
$$

As Head and Ries (2008) shows, with the right assumption on the error term, we can use maximum likelhood estimation of a count data model (such as a (quasi-)Poisson) to estimate the vector of parameters of interest in the model, $\boldsymbol{\theta}$. We can control for the outward $\left(O_{i}\right)$, inward $\left(I_{j}\right)$, and sectoral $\left(S_{k}\right)$ effects using sets of parent-country, hostcountry, and sectoral fixed effects, respectively.

The focus of our analysis is the impact of the vector of frictions, $\mathbf{D}_{i j k}$, on crossborder M\&A. In Head and Ries (2008), these frictions only vary by cross-border pair. As discussed above, this makes it challenging to identify the effects as due to monitoring 
costs because there are a number of other reasons why cross-border distances could limit cross-border M\&A. In order to identify whether monitoring costs represent a mechanism for the inverse relationship between bilateral-country distances and FDI, we pursue a strategy similar to Rajan and Zingales (1998), which has been used in many subsequent empirical studies. ${ }^{10}$ From the $0^{*}$ NET data described above we have sectoral information on the degree to which monitoring and related activities matter across sectors. If greater cultural and physical distances increase monitoring costs, then we expect that the FDI-reducing impact of these distances will be greater for sectors where monitoring is more important. Formally, we model this as $\mathbf{D}_{i j k}=M_{k} \times \mathbf{D}_{i j}$, where $M_{k}$ is the $0^{*}$ NET variable measuring the "monitoring importance" across sectors. In order to control for other potential mechanisms for the relationship between these distances and FDI, we continue to include the vector of bilateral distance measures $\left(\mathbf{D}_{i j}\right)$ separately.

Our vector of physical and cultural distance measures include the same ones used by Head and Ries (2008). These are Distance $_{i j}$, a measure of the physical distance between the home and the host country, LangDist $_{i j}$, a measure of the dissimilarity of language between the two countries, and an indicator when the two countries do not have a past colonial relationship, NoColony ${ }_{i j} .{ }^{11}$ These data come from the CEPII website (www.cepii.fr) and have been used by many others for statistical studies of international economic activity.

\footnotetext{
${ }^{10}$ In the international trade and FDI literature, such studies include Alfaro et al. (2004), Manova (2008), Chor and Manova (2012), and Blonigen (2015).

${ }^{11}$ One difference from Head and Ries (2008) is that we define all these variables in terms of frictions, so that they all have an expected inverse correlation. We also follow Melitz and Toubal (2014) and use the percentage of people from each country that share a common native language (rather than official language) and invert the measure so it represents a language dissimilarity measure.
} 
We also include two cultural distance variables not included in Head and Ries (2008), but often used in other studies. The first is CultureDist $_{i j}$, measuring the cultural distance between the parent and the host country. We use Kogut and Singh's (1988) approach which is a composite index formed based on the weighted difference between the four cultural dimensions (i.e. power distance, uncertainty avoidance, masculinity/femininity, and individualism) of each country. The second cultural variable we include is religious distance, ReligDist $_{i j}$. We use information from the CIA Factbook to gather shares of population in each country that identify with the following religions: Catholic, Protestant Christian, Muslim, Buddhist, Hindu, Orthodox or Jewish. For each country pair we total the share (in decimal form) of their populations with a common religion and then subtract from one.

Finally, we include a vector of bilateral country-pair control variables $\left(\mathbf{X}_{i j}\right)$ that empirical FDI studies often include and find to have statistical support. These are common national border $\left(\operatorname{CONTIG}_{i j}\right)$, common currency ( $\left.\operatorname{ComCurr}_{i j}\right)$, common legal systems ( ComLegal $\left._{i j}\right)$, the (log) GDP of the parent country and of the host country, the (log) difference in GDP per capita between the parent and host countries ( $\left.\triangle \log p c G D P_{i j}\right)$ and its squared value, the absolute value of the corporate tax differences between countries $\left(\log \left(1+\left|\Delta \operatorname{CorpTax}_{i j}\right|\right)\right)$, an interaction of this tax-difference variable with an indicator that the parent country is the higher tax country $(\log (1+/ \Delta$ CorpTaxij]()xAcqHighTax), whether the two countries have a double taxation treaty in place $\left(D T T_{i j}\right)$, whether the two countries have a bilateral investment treaty in place $\left(B I T_{i j}\right)$ and an indicator whether the two countries have a biliateral free trade agreement with each other $\left(W T O F T A_{i j}\right)$. For completeness, we also include domestic acquisitions 
in our sample, where the parent and host country are the same. Because there may be something inherently different to these transactions than what is captured by our control variables, we also include an indicator variable that the acquisition is domestic only $\left(\right.$ Domestic $\left._{i j}\right)$. Appendix B provides descriptions of these variables and information on their data sources, as well as summary statistics. ${ }^{12}$

Our final empirical specification is:

$$
F_{i j k}=E\left[F_{i j k}\right] \eta_{i j k}=\exp \left[O_{i}+I_{j}+S_{k}-\left(M_{k} \times \mathbf{D}_{i j}\right) \boldsymbol{\theta}-\mathbf{D}_{i j} \boldsymbol{\gamma}-\mathbf{X}_{i j} \boldsymbol{\beta}\right] \eta_{i j k}
$$

where $\{\boldsymbol{\theta}, \boldsymbol{\gamma}, \boldsymbol{\beta}\}$ are the set of parameters to be estimated using Pseudo-Poisson Maximum Likelihood (PPML) methods. As indicated above, we control for the outward $\left(O_{i}\right)$, inward $\left(I_{j}\right)$, and sectoral $\left(S_{k}\right)$ effects using sets of parent-country, host-country, and sectoral fixed effects, respectively.

\section{EMPIRICAL RESULTS}

We begin the empirical results by estimating equation (10) using PPML methods to estimate the impacts of cross-border frictions on M\&A activity for our full sample of cross-border M\&A transactions across the Top 50 countries over the 1985-2014 period. We then explore the robustness of our results to alternative samples, including the subset of M\&A activity between only OECD countries and different time periods. Finally, we turn to examining the extent to which the monitoring cost effect of FDI explains the substantial differences we see in cross-border M\&A activity across industrial sectors.

\footnotetext{
${ }^{12}$ Our regressor set is informed by previous FDI studies, including Rossi and Volpin (2004), Di Giovanni (2005) Head and Ries (2008), Hijzen et al. (2008), Erel et al. (2012), and Blonigen and Piger (2014).
} 


\subsection{Evidence for the Monitoring-Cost Effect on FDI}

Column 1 of Table 5 provides the results for our base specification for the full sample of Top 50 countries when excluding any monitoring cost variables. Many of the variables have the expected sign and are statistically significant. The overall fit of the equation is strong with an R-squared statistic of 0.843 . All the gravity variables have the expected sign and are statistically significant at the $1 \%$ level, including our physical and cultural friction terms - Dist, LangDist, CultDist, NoColony, and ReligDist which we list at the top of the table.

The economic significance of the friction variables is high as well. A standard deviation increase in physical distance, cultural distance, and religious distance reduces cross-border M\&A activity by 38.7\%, 20.6\%, and 33.8\%, respectively. Countries with no common native language have a $44.1 \%$ lower probablity of crossborder M\&A than those that share a native language, and countries with no colonial connection have a $41.3 \%$ lower probablity of cross-border M\&A than those with a colonial relationship.

Column 2 of Table 5 introduces our $0 *$ NET measure of monitoring importance as an independent variable into the specification and shows that it does not have a statistically-significant direct impact on cross-border M\&A activity. Industries that involve a higher degree of monitoring skills for its employees do not inherently have higher or lower M\&A activity. We have tried a variety of alternative specifications, including ones with interactions of the monitoring importance variable with frictions, and the direct impact of the monitoring importance variable is always statistically insignificant. This indicates that the impact of monitoring importance only operates 
through its interactions with cross-border frictions, not through any direct effect. This is helpful to us in two ways. First, note that we cannot include industry fixed effects when we include monitoring importance as an independent variable because it only varies by industry. The exclusion of industry fixed effects leads to a very large reduction in the R-squared of the specification, suggesting that there are many industry-specific effects that matter for M\&A activity. Because of the evidence that monitoring importance is not significant on its own, we can proceed with specifications that include industry fixed effects that subsume the direct impact of monitoring importance. This also helps in calculations of the economic significance (marginal effects) of monitoring importance because we can assume that it only operates through its interactions with our friction variables and thus we do not have to estimate its direct impact separately, which can only be done by excluding industry fixed effects.

Columns 3 through 8 of Table 5 provide evidence for the impact of monitoring costs on cross-border M\&A through interactions of the monitoring importance variable (M) with cross-border frictions. We introduce each interaction with a different friction separately and then include all the interactions in the specification in the last column. Separately, each of the interaction terms has the expected negative coefficient and is statistically significant at the $1 \%$ level. Due to multicollinearity, the individual coefficients on the interaction terms are generally insignificant in the last column, except for the interaction with physical distance, but they are jointly significant at the $1 \%$ level (F-test value of 21.95 with a p-value of 0.001 ). In total, these results provide statistical evidence for the monitoring-cost effect on FDI. 
It is noteworthy that there continues to be an independent negative correlation between the physical and cultural friction variables even after introducing the interaction terms, suggesting that the effects of the cross-border physical and cultural distances on FDI are not solely due to monitoring costs. There are a number of other reasons why these cross-border frictions may be substantial and independent of the monitoring cost effect we estimate, including the difficulty of identifying appropriate targets for acquisition in countries that are physically and culturally different. The size of the direct effects of the cross-border frictions is significantly reduced when introducing the interaction terms separately in columns 3-7, suggesting that monitoring costs are a significant explanation for how these frictions affect FDI. The magnitude of the coefficient on the physical distance effect falls by about 25\% (from 0.325 to -0.242 ) when the interaction of physical distance with monitoring importance is introduced. Analogously, the magnitude of the coefficients on language distance, cultural distance, colonial relationship, and religious distance fall by about $22 \%, 57 \%$, $40 \%$, and $9 \%$, respectively. However, these reductions are less pronounced (or nonexistent) when all the interactions are included together in column 8, except for physical distance. This evidence suggests that physical distance is the friction where monitoring costs are mainly operating.

To examine this further and gauge the economic significance of monitoring costs, we use our column 8 estimates to calculate the marginal effect on cross-border M\&A activity when we increase monitoring importance by a standard deviation. This effect works through the combined effect of its interactions with the cultural and 
physical distance friction terms. ${ }^{13}$ At the mean of the other variables in the regressor set, we find that a standard deviation increase in the monitoring importance is associated with a decrease in M\&A activity of $41.9 \%$. This effect is statistically significant at the $1 \%$ level. We also find that $92.6 \%$ of this effect is driven by the interaction of monitoring importance with the physical distance term.

\subsection{Robustness}

We explore the robustness of our results in a variety of ways in this section. Perhaps the most obvious check is to reduce our sample to only the cross-border M\&A transactions between OECD countries. As indicated earlier, the majority of crossborder transactions in the world occur between the OECD countries and, relatedly, these are the richer and more-developed countries. Because of this there may be structural differences in how cultural and physical distance frictions operate on international transactions between these countries than on transactions involving a non-OECD country.

Table 6 provides analogous statistical results for the sample of cross-border M\&A activity between OECD countries as what we reported in Table 5 for the full sample. The results are qualitatively very similar. All the cultural and physical distance frictions are negative and significant as with the full sample, and the other control variables are generally the same sign. As with the full sample, the direct effect of monitoring importance is insignficant (see column 2). The interactions of

\footnotetext{
${ }^{13}$ Again, we assume that the direct effect of monitoring importance, which is subsumed in the industry fixed effects, is zero because we find it is always statistically insignificant in the wide variety of specifications we have run.
} 
monitoring importance with the physical and cultural distance frictions are also all negative and statistically significant when introduced separately with the exception of religious distance. When the full set of interactions of monitoring importance with cultural and physical distance frictions are introduced in the final column of Table 6 , they all have the expected negative sign, but only colonial relationship is statistically significant. However, just as with the full sample, these interactions are jointly statistically significant at the $1 \%$ level and a one-standard deviation increase in monitoring importance is associated with a nearly identical decline in the dependent variable $(40.7 \%)$ as in the full sample. Also, most of this joint effect $(76.4 \%)$ is operating through the interaction with the physical distance variable. In summary, the results for the OECD-only sample is surprisingly similar to the full sample.

Table 7 provides evidence that the joint significance of the monitoringimportance interactions and their joint marginal impact on cross-border M\&A activity is robust to a variety of robustness checks. Columns 1 and 2 show results from the full sample and the OECD-only sample that we just discussed. Column 3 shows the results when we estimate our model on the sample of observations that involve a non-OECD country. Columns 4 and 5 show that these key results are robust to whether we examine the first half or second half of our sample. We find no statistical difference in any of the monitoring-importance interactions across the two sub-samples. Column 6 shows the robustness of our result when we eliminate domestic acquisitions from our sample. Domestic observations comprise a small fraction of our sample, but are also unusual in that the cultural and physical distance variables take values indicating complete absence of any cross-border distances for these observations. 
Columns 7 through 9 examine the robustness of our results to variations in how we measure monitoring importance. Recall from section 2 above that our monitoring importance variable is an average measure across "cultural skills", "language skills", and "monitoring skills" identified in the $0^{*}$ NET database. As an alternative, we created a new measure of monitoring importance derived only from monitoring skills. We then analogously created a cultural importance measure from the cultural skills data, and a languge importance measure from the langugage skills data. We interacted this new monitoring importance measure with physical distance (Dist), the language importance measure with language distance (LangDist), and the cultural importance measure with our remaining cultural distance variables (CultDist, NoColony, and ReligDist). Column 7 shows that we get qualitatively identical results when we interact these alternative skill importance variables with our cultural, language and physical distance measures. In column 8 , we form a principal component from these three terms (monitoring importance, cultural importance, and language importance) and interact the principal component with our cultural, language and physical distance terms. This too yields qualitatively identical results. Lastly, in column 9, we strip down the monitoring importance variable to just one of the thirteen $0^{*}$ NET occupational skills - the "monitoring" skill. Once again we find qualitatively identical results.

In summary, the evidence for a statistically and economically significant effect of monitoring importance on cross-border M\&A activity is highly robust across a number of alternative samples and measures of monitoring importance. A standard deviation increase in monitoring importance is associated with a decreased level of 
cross-border M\&A activity that ranges from $27 \%$ to over $51 \%$. Another robust result is that the majority of this effect is operating through the physical distance term.

\subsection{Monitoring importance explains a significant portion of the difference in cross- border M\&A activity across industrial sectors}

Manufacturing has a disproportionate share of FDI activity in the world economy relative to other sectors and it also has occupations that generally require less monitoring skills. An important question is the extent to which this monitoring importance can explain differences in cross-border M\&A activity in manufacturing versus other sectors. We use our estimates from the final column of Tables 5 and 6 to directly examine this question.

Table 8 provides our analysis for both the full sample (panel A) and the OECDonly sample (panel B). The first column of data provides the predicted number of bilateral cross-border M\&As per 5-year period for 2-digit SIC codes connected with the sector at the means of all the regressors. For example, the model's predicted number of cross-border M\&A between any pair of countries in the full sample during a fiveyear period for a 2-digit SIC in manufacturing is 0.0254 at the means of the data. The analogous number for a non-manufacturing 2-digit SIC is 0.0165 . These averages roughly double for the OECD-only sample with a 0.0489 predicted value for manufacturing and 0.0334 for non-manufacturing.

In column 2, we provide the predicted value of the dependent variable when we modify the data so that the sector has the same level of monitoring importance as manufacturing, keeping the level of all the other variables in the regressor set at their means. Column 3 provides the percentage difference between columns 1 and 2 to show 
how much the predicted number of cross-border M\&As changes when we put the sector's monitoring importance at the same level as seen in manufacturing, and column 4 provides the F-test and associated p-value indicating the statistical significance of this difference.

As Table 8 shows, M\&A activity would be higher for all non-manufacturing sectors (with the exception of mining) if monitoring importance would be at the same level as the manufacturing sector. On average, our estimates suggest that cross-border M\&A activity would be $50.3 \%$ higher in the non-manufacturing sectors in our full sample, and $41.3 \%$ higher in the OECD-only sample. Non-manufacturing sectors are very heterogeneous, spaning mining to services, so rows 3 through 9 provide the analysis for these sectors at the 1-digit level. The results follow directly from the summary statistics in Table 1 indicating which sectors require a greater amount of monitoring given their occupational composition. If monitoring importance were as low as that required in manufacturing, the high-monitoring sectors of wholesale trade, retail trade, and finance, insurance, and real estate would see their cross-border M\&A activity approximately double according to our estimates. There would be much smaller increases (around 5-10\%) in services, construction and transportation, communications, and utilities, and an actual decrease of around 8-9\% in the mining sector where monitoring is less important than in manufacturing. Overall, monitoring importance is a highly significant factor in explaining lower cross-border M\&A activity in non-manufacturing, especially for the wholesale trade, retail trade, and finance, insurance, and real estate sectors. 


\section{CONCLUSION}

Prior literature nearly always finds that physical and cultural distances significantly impede a wide range of international economic phenomena. However, while there are a myriad of possible explanations for why these frictions are so significant, there is typically little evidence for which mechanisms are truly responsible for their effects.

In this paper, we provide a way to identify the role of monitoring costs as a mechanism behind the deleterious effects of physical and cultural distance on crossborder M\&A activity, as proposed by Head and Ries (2008). We find significant

evidence for this channel and show that differences in monitoring importance of affiliates across industries can explain a significant portion of the variation in crossborder M\&A we observe across sectors of the economy.

At the same time, we find that physical and cultural distances continue to have a negative effect on cross-border M\&A activity independent of the monitoring cost mechanism, indicating that there are additional mechanisms that are salient for understanding how and why these frictions matter. Further study to fully understand the mechanisms behind the strong impact of physical and cultural distance is important because industrial development and globalization is inherently linked to the ability of firms to engage in cross-border M\&A activity. In addition, policymakers often pursue strategies to encourage FDI activity in order to improve employment and productivity in their economies, but it is unlikely that their strategies will be effective without better knowledge of the mechanisms that can impede FDI. 


\section{References}

Aizenman, J. and Spiegel, M. M. (2006). Institutional efficiency, monitoring costs and the investment share of FDI. Review of International Economics, 14(4), 683-697.

Alfaro, L., Chanda, A., Kalemli-Ozcan, S. and Sayek, S. (2004). FDI and economic growth: the role of local financial markets. Journal of international economics, 64(1), 89-112.

Anderson, T. (November 2014) "Operations of US affiliates of foreign companies," Survey of Current Business (http://www.bea.gov/scb/pdf/2014/11\%20November/1114_activities_of_u.s_affilia tes_of_foreign_multinational_enterprises.pdf).

Barefoot, K.B. (November 2013) "U.S. multinational companies: Operations of U.S. parents and foreign affiliates in 2011," Survey of Current Business https://www.bea.gov/scb/pdf/2013/11\%20November/1113_mnc.pdf

Bénassy-Quéré, A., Coupet, M., and Mayer, T. (2007). Institutional determinants of foreign direct investment. World Economy, 30(5), 764-782.

Blonigen, B.A., (2015). Industrial policy and downstream export performance. The Economic Journal, 126(595), 1635-1659.

Blonigen, B.A. and Piger, J. (2014). Determinants of foreign direct investment. Canadian Journal of Economics/Revue canadienne d'économique, 47(3), 775-812.

Chor, D. and Manova, K. (2012). Off the cliff and back? Credit conditions and international trade during the global financial crisis. Journal of international economics, 87(1), 117-133.

Davies, R.B., Desbordes, R., and Ray, A. (2018). Greenfield versus merger and acquisition FDI: Same wine, different bottles?. Canadian Journal of Economics/Revue canadienne d'économique, 51(4), 1151-1190.

Di Giovanni, J. (2005) "What drives capital flows? The case of cross-border M\&A activity and financial deepening," Journal of International Economics 65(1): 127-149.

Elrod, A.A., Lindberg, B.M. and Morgan, E.T. (May 2013). "Annual industry accounts: Advance statistics on GDP by industry for 2012," Survey of Current Business (http://www.bea.gov/scb/pdf/2013/05\%20May/0513_annual_industry-acctstext.pdf).

Erel, I., Liao, R. C., and Weisbach, M. S. (2012). “Determinants of cross-border mergers and acquisitions," The Journal of Finance 67(3): 1045-1082. 
Felbermayr, G., and Jung, B. (2011) "Trade intermediation and the organization of exporters," Review of International Economics 19(4): 634-648.

Feliciano, Z. M. and Sun, J. (2016) "Foreign entry into U.S. service industry by takeovers and the creation of new firms," Contemporary Economic Policy 34(3): 500512.

Habib, M., \& Zurawicki, L. (2002). Corruption and foreign direct investment. Journal of International Business Studies, 33(2), 291-307.

Head, K. and Ries, J. (2008) "FDI as an outcome of the market for corporate control: Theory and evidence," Journal of International Economics 74(1): 2-20.

Hijzen, A., Görg, H. and Manchin, M. (2008). "Cross-border mergers and acquisitions and the role of trade costs," European Economic Review 52(5), 849-866.

Kleinert, J., and Toubal, F. (2013) "Production versus distribution-oriented FDI," Review of World Economics 149(3): 423-442.

Kogut, B. and Singh, H. (1988). "The effect of national culture on the choice of entry mode," Journal of International Business Studies, 19(3): 411-432.

Krautheim, S. (2013) "Export-supporting FDI," Canadian Journal of Economics 46(4): 1571-1605.

Manova, K. (2008). Credit constraints, equity market liberalizations and international trade. Journal of International Economics, 76(1), 33-47.

Melitz, J., \& Toubal, F. (2014). Native language, spoken language, translation and trade. Journal of International Economics, 93(2), 351-363.

Morosini, P., Shane, S. and Singh, H. (1998) "National cultural distance and cross-border acquisition performance." Journal of International Business Studies 29(1): 137-158.

Raimondi, V., and Scoppola, M. (2018). Foreign Land Acquisitions and Institutional Distance. Land Economics, 94(4), 517-540.

Ramasamy, B. and Yeung, M. (2010). "The determinants of foreign direct investment in services," The World Economy 33(4): 573-596.

Rossi, S. and Volpin, P. F. (2004). "Cross-country determinants of mergers and acquisitions," Journal of Financial Economics 74(2), 277-304.

Stein, E., \& Daude, C. (2007). Longitude matters: Time zones and the location of foreign direct investment. Journal of International Economics, 71(1), 96-112. 
United Nations Conference on Trade and Development (UNCTAD) (2015) World Investment Report: Reforming International Investment Governance. Geneva and New York: United Nations. 
Table 1: Summary Statistics for the O*NET Variable

\begin{tabular}{lccccc}
\hline Sector & Mean & $\begin{array}{c}\text { St. } \\
\text { Dev. }\end{array}$ & Min & Max & Obs. \\
\hline \hline & & & & & \\
All Sectors & 0.060 & 0.050 & 0.012 & 0.239 & 70 \\
$\quad$ Manufacturing & 0.035 & 0.010 & 0.018 & 0.059 & 20 \\
$\quad$ Non-Manufacturing & 0.071 & 0.055 & 0.012 & 0.239 & 50 \\
$\quad$ Mining & 0.025 & 0.012 & 0.015 & 0.041 & 4 \\
$\quad$ Construction & 0.038 & 0.014 & 0.030 & 0.055 & 3 \\
$\quad$ Transportation, communications, & & & & & \\
$\quad$ and utilities & 0.039 & 0.035 & 0.012 & 0.121 & 9 \\
$\quad$ Wholesale trade & 0.108 & 0.007 & 0.103 & 0.113 & 2 \\
$\quad$ Retail trade & 0.144 & 0.063 & 0.022 & 0.239 & 8 \\
$\quad$ Finance, insurance, and real estate & 0.125 & 0.029 & 0.090 & 0.176 & 7 \\
$\quad$ Services & 0.045 & 0.023 & 0.014 & 0.095 & 15 \\
\hline
\end{tabular}

Notes: Authors calculations. O*NET variable is a measure of the importance of monitoring, language and cultural skills needed for the composition of occupations in an industrial sector. See text for further description of the construction of the measure. 
Table 2: Sectors with Highest and Lowest Importance for MonitoringRelated Skills

Panel A: Highest Ten Sectors for Monitoring- Related Skills

\begin{tabular}{lcc}
\hline Sector & SIC & O*NET Value \\
\hline \hline Apparel and Accessory Stores & 56 & 0.239 \\
$\begin{array}{l}\text { Security and Commodity Brokers, Dealers, } \\
\text { Exchanges, and Services }\end{array}$ & 62 & 0.176 \\
$\begin{array}{l}\text { Building Materials, Hardware, Garden Supply, and } \\
\text { Mobile Home Dealers }\end{array}$ & 52 & 0.173 \\
Home Furniture, Furnishings, and Equipment & 57 & 0.163 \\
Stores & 59 & 0.159 \\
Miscellaneous Retail & 53 & 0.158 \\
General Merchandise Stores & 67 & 0.137 \\
Holding and Other Investment Offices & 55 & 0.135 \\
Automotive Dealers and Gasoline Service Stations & 64 & 0.134 \\
Insurance Agents, Brokers, and Service & 61 & 0.127 \\
Non-Depository Credit Institutions & & \\
\hline
\end{tabular}

Panel B: Lowest Ten Sectors for Monitoring- Related Skills

\begin{tabular}{lcc}
\hline Sector & SIC & O*NET Value \\
\hline \hline Local and Suburban Transit & 41 & 0.012 \\
Legal Services & 81 & 0.014 \\
Transportation By Air & 45 & 0.014 \\
Railroad Transportation & 40 & 0.015 \\
Coal Mining & 12 & 0.015 \\
Health Services & 80 & 0.016 \\
Metal Mining & 10 & 0.019 \\
Educational Services & 82 & 0.021 \\
Motor Freight Transportation and Warehousing & 42 & 0.021 \\
Eating and Drinking Places & 58 & 0.022 \\
\hline
\end{tabular}

Notes: Authors calculations. The $0^{*}$ NET variable is a measure of the importance of monitoring, language and cultural skills needed for the composition of occupations in an industrial sector. See text for further description of the construction of the measure. 
Table 3: Sectoral Composition of Cross-border M\&A Across Different Samples

\begin{tabular}{lcc}
\hline & Top 50 & OECD \\
\hline Manufacturing & $38 \%$ & $39 \%$ \\
Non-Manufacturing & $62 \%$ & $61 \%$ \\
Mining & & \\
Construction & $6 \%$ & $5 \%$ \\
Transportation, communications, & $1 \%$ & $1 \%$ \\
$\quad$ and utilities & $9 \%$ & $8 \%$ \\
Wholesale trade & $6 \%$ & $6 \%$ \\
Retail trade & $3 \%$ & $3 \%$ \\
Finance, insurance and real estate & $12 \%$ & $11 \%$ \\
Services & $24 \%$ & $26 \%$ \\
\hline
\end{tabular}

Notes: Data from Thomson Reuters SDC Platinum M\&A Database, 19852014. Top 50 and OECD sample of countries are defined in Appendix A. 
Table 4: Share of Manufacturing in Domestic and Cross-border M\&A for Various Samples and Top 10 Target Countries

\begin{tabular}{lrrr|rrr}
\hline & \multicolumn{3}{c}{ Domestic Acquisitions } & \multicolumn{2}{c}{ Cross-border Acquisitions } \\
\cline { 2 - 7 } & $\begin{array}{r}\text { Manufac } \\
\text { turing }\end{array}$ & $\begin{array}{c}\text { Non- } \\
\text { Manufac } \\
\text { turing }\end{array}$ & $\begin{array}{c}\text { Share of } \\
\text { Manufac } \\
\text { turing }\end{array}$ & $\begin{array}{c}\text { Non- } \\
\text { Manufac } \\
\text { turing }\end{array}$ & $\begin{array}{c}\text { Share of } \\
\text { Manufac } \\
\text { turing }\end{array}$ & $\begin{array}{c}\text { Manufac } \\
\text { turing }\end{array}$ \\
\hline \hline Top 50 Sample & 131,545 & 346,296 & 0.28 & 50,289 & 82,537 & 0.38 \\
OECD Sample & 109,843 & 294,606 & 0.27 & 37,732 & 59,261 & 0.39 \\
& & & & & & \\
Top 10 Target Countries & & & & & & \\
Australia Targets & 2,812 & 14,471 & 0.16 & 1,441 & 4,951 & 0.23 \\
Canada Targets & 3,667 & 17,743 & 0.17 & 2,561 & 5,911 & 0.30 \\
China Targets & 6,338 & 8,596 & 0.42 & 2,487 & 3,318 & 0.43 \\
France Targets & 7,332 & 12,910 & 0.36 & 3,829 & 4,477 & 0.46 \\
Germany Targets & 8,014 & 12,601 & 0.39 & 5,326 & 5,809 & 0.48 \\
Italy Targets & 3,024 & 5,360 & 0.36 & 2,220 & 2,041 & 0.52 \\
Netherlands Targets & 1,735 & 4,426 & 0.28 & 1,592 & 2,653 & 0.38 \\
Spain Targets & 3,035 & 6,963 & 0.30 & 1,560 & 2,917 & 0.35 \\
U.K. Targets & 12,168 & 34,591 & 0.26 & 5,108 & 10,873 & 0.32 \\
U.S. Targets & 46,595 & 134,520 & 0.26 & 9,649 & 16,034 & 0.38 \\
\hline
\end{tabular}

Notes: Authors calculations using data from Thomson Reuters SDC Platinum M\&A Database, 1985-2014. Top 50 and OECD sample of countries are defined in Appendix A. 
Table 5: Pseudo-Poisson Maximum Likelihood Estimates of the Determinants of Cross-Border M\&A - Full Sample

\begin{tabular}{|c|c|c|c|c|c|c|c|c|}
\hline Independent Variables & (1) & $(2)$ & (3) & $(4)$ & (5) & (6) & (7) & (8) \\
\hline Dist & $\begin{array}{c}-0.325^{* * *} \\
(0.024)\end{array}$ & $\begin{array}{c}-0.325^{* * *} \\
(0.024)\end{array}$ & $\begin{array}{c}-0.242^{* * *} \\
(0.043)\end{array}$ & $\begin{array}{c}-0.325^{* * *} \\
(0.024)\end{array}$ & $\begin{array}{c}-0.325^{* * *} \\
(0.024)\end{array}$ & $\begin{array}{c}-0.325^{* * *} \\
(0.024)\end{array}$ & $\begin{array}{c}-0.325^{* * *} \\
(0.024)\end{array}$ & $\begin{array}{c}-0.253^{* * *} \\
(0.050)\end{array}$ \\
\hline LangDist & $\begin{array}{c}-0.993^{* * *} \\
(0.057)\end{array}$ & $\begin{array}{c}-0.993^{* * *} \\
(0.057)\end{array}$ & $\begin{array}{c}-0.991^{* * *} \\
(0.056)\end{array}$ & $\begin{array}{c}-0.772^{* * *} \\
(0.090)\end{array}$ & $\begin{array}{c}-0.988^{* * *} \\
(0.056)\end{array}$ & $\begin{array}{c}-0.993^{* * *} \\
(0.057)\end{array}$ & $\begin{array}{c}-0.993^{* * *} \\
(0.057)\end{array}$ & $\begin{array}{c}-0.963^{* * *} \\
(0.132)\end{array}$ \\
\hline CultDist & $\begin{array}{c}-0.144^{* * *} \\
(0.019)\end{array}$ & $\begin{array}{c}-0.144^{* * *} \\
(0.019)\end{array}$ & $\begin{array}{c}-0.144^{* * *} \\
(0.019)\end{array}$ & $\begin{array}{c}-0.144^{* * *} \\
(0.019)\end{array}$ & $\begin{array}{l}-0.062^{*} \\
(0.035)\end{array}$ & $\begin{array}{c}-0.144^{* * *} \\
(0.019)\end{array}$ & $\begin{array}{c}-0.144^{* * *} \\
(0.018)\end{array}$ & $\begin{array}{c}-0.141^{* * *} \\
(0.032)\end{array}$ \\
\hline NoColony & $\begin{array}{c}-0.496^{* * *} \\
(0.028)\end{array}$ & $\begin{array}{c}-0.496^{* * *} \\
(0.028)\end{array}$ & $\begin{array}{c}-0.498^{* * *} \\
(0.028)\end{array}$ & $\begin{array}{c}-0.496^{* * *} \\
(0.028)\end{array}$ & $\begin{array}{c}-0.497^{* * *} \\
(0.028)\end{array}$ & $\begin{array}{c}-0.297^{* * *} \\
(0.073)\end{array}$ & $\begin{array}{c}-0.496^{* * *} \\
(0.028)\end{array}$ & $\begin{array}{c}-0.446^{* * *} \\
(0.070)\end{array}$ \\
\hline ReligDist & $\begin{array}{c}-1.697^{* * *} \\
(0.079)\end{array}$ & $\begin{array}{c}-1.697^{* * *} \\
(0.079)\end{array}$ & $\begin{array}{c}-1.700^{* * *} \\
(0.079)\end{array}$ & $\begin{array}{c}-1.698^{* * *} \\
(0.079)\end{array}$ & $\begin{array}{c}-1.697^{* * *} \\
(0.079)\end{array}$ & $\begin{array}{c}-1.697^{* * *} \\
(0.079)\end{array}$ & $\begin{array}{c}-1.537^{* * *} \\
(0.149)\end{array}$ & $\begin{array}{c}-1.725^{* * *} \\
(0.145)\end{array}$ \\
\hline Monitoring Importance (M) & & $\begin{array}{c}0.625 \\
(2.157)\end{array}$ & & & & & & \\
\hline Mx Dist & & & $\begin{array}{c}-1.318^{* * *} \\
(0.431)\end{array}$ & & & & & $\begin{array}{c}-1.150^{* *} \\
(0.555)\end{array}$ \\
\hline Mx LangDist & & & & $\begin{array}{c}-3.658^{* * *} \\
(1.253)\end{array}$ & & & & $\begin{array}{l}-0.459 \\
(1.956)\end{array}$ \\
\hline Mx CultDist & & & & & $\begin{array}{c}-1.401^{* * *} \\
(0.491)\end{array}$ & & & $\begin{array}{c}-0.061 \\
(0.306)\end{array}$ \\
\hline M x NoColony & & & & & & $\begin{array}{c}-3.248^{* * *} \\
(1.084)\end{array}$ & & $\begin{array}{c}-0.897 \\
(1.286)\end{array}$ \\
\hline Mx ReligDist & & & & & & & $\begin{array}{c}-2.527 \\
(2.149)\end{array}$ & $\begin{array}{c}0.392 \\
(1.998)\end{array}$ \\
\hline Contig & $\begin{array}{c}0.313^{* * *} \\
(0.037)\end{array}$ & $\begin{array}{c}0.313^{* * *} \\
(0.037)\end{array}$ & $\begin{array}{c}0.315^{* * *} \\
(0.038)\end{array}$ & $\begin{array}{c}0.313^{* * *} \\
(0.037)\end{array}$ & $\begin{array}{c}0.313^{* * *} \\
(0.037)\end{array}$ & $\begin{array}{c}0.313^{* * *} \\
(0.037)\end{array}$ & $\begin{array}{c}0.313^{* * *} \\
(0.037)\end{array}$ & $\begin{array}{c}0.315^{* * *} \\
(0.038)\end{array}$ \\
\hline
\end{tabular}




\begin{tabular}{|c|c|c|c|c|c|c|c|c|}
\hline ComCurr & $\begin{array}{c}-0.111^{* * *} \\
(0.042)\end{array}$ & $\begin{array}{c}-0.111^{* * *} \\
(0.042)\end{array}$ & $\begin{array}{c}-0.109 * * * \\
(0.042)\end{array}$ & $\begin{array}{c}-0.111^{* * *} \\
(0.042)\end{array}$ & $\begin{array}{c}-0.110^{* * *} \\
(0.042)\end{array}$ & $\begin{array}{c}-0.111^{* * *} \\
(0.042)\end{array}$ & $\begin{array}{c}-0.111^{* * *} \\
(0.042)\end{array}$ & $\begin{array}{c}-0.108^{* *} \\
(0.042)\end{array}$ \\
\hline ComLegal & $\begin{array}{c}0.049 \\
(0.038)\end{array}$ & $\begin{array}{c}0.049 \\
(0.038)\end{array}$ & $\begin{array}{c}0.048 \\
(0.038)\end{array}$ & $\begin{array}{c}0.049 \\
(0.038)\end{array}$ & $\begin{array}{c}0.048 \\
(0.038)\end{array}$ & $\begin{array}{c}0.049 \\
(0.038)\end{array}$ & $\begin{array}{c}0.049 \\
(0.038)\end{array}$ & $\begin{array}{c}0.047 \\
(0.038)\end{array}$ \\
\hline WTOFTA & $\begin{array}{c}0.584^{* * *} \\
(0.053)\end{array}$ & $\begin{array}{c}0.584^{* * *} \\
(0.053)\end{array}$ & $\begin{array}{c}0.591^{* * *} \\
(0.054)\end{array}$ & $\begin{array}{c}0.584^{* * *} \\
(0.053)\end{array}$ & $\begin{array}{c}0.584^{* * *} \\
(0.053)\end{array}$ & $\begin{array}{c}0.584^{* * *} \\
(0.053)\end{array}$ & $\begin{array}{c}0.584^{* * *} \\
(0.053)\end{array}$ & $\begin{array}{c}0.592^{* * *} \\
(0.054)\end{array}$ \\
\hline Log GDP acquirer & $\begin{array}{c}0.973^{* * *} \\
(0.150)\end{array}$ & $\begin{array}{c}0.973^{* * *} \\
(0.150)\end{array}$ & $\begin{array}{c}0.973^{* * *} \\
(0.150)\end{array}$ & $\begin{array}{c}0.973^{* * *} \\
(0.150)\end{array}$ & $\begin{array}{c}0.973^{* * *} \\
(0.150)\end{array}$ & $\begin{array}{c}0.973^{* * *} \\
(0.150)\end{array}$ & $\begin{array}{c}0.973^{* * *} \\
(0.150)\end{array}$ & $\begin{array}{c}0.973^{* * *} \\
(0.150)\end{array}$ \\
\hline Log GDP target & $\begin{array}{c}0.729 * * * \\
(0.179)\end{array}$ & $\begin{array}{c}0.729^{* * *} \\
(0.179)\end{array}$ & $\begin{array}{c}0.728^{* * *} \\
(0.179)\end{array}$ & $\begin{array}{c}0.729 * * * \\
(0.179)\end{array}$ & $\begin{array}{c}0.729^{* * *} \\
(0.179)\end{array}$ & $\begin{array}{c}0.729 * * * \\
(0.179)\end{array}$ & $\begin{array}{c}0.729^{* * *} \\
(0.179)\end{array}$ & $\begin{array}{c}0.728^{* * *} \\
(0.179)\end{array}$ \\
\hline$\Delta \log p c G D P[$ Tar-Acq] & $\begin{array}{c}-0.030 \\
(0.193)\end{array}$ & $\begin{array}{c}-0.030 \\
(0.193)\end{array}$ & $\begin{array}{c}-0.031 \\
(0.193)\end{array}$ & $\begin{array}{c}-0.030 \\
(0.193)\end{array}$ & $\begin{array}{c}-0.030 \\
(0.193)\end{array}$ & $\begin{array}{c}-0.030 \\
(0.193)\end{array}$ & $\begin{array}{c}-0.030 \\
(0.193)\end{array}$ & $\begin{array}{c}-0.031 \\
(0.193)\end{array}$ \\
\hline$(\triangle \log p c G D P)^{\wedge} 2$ & $\begin{array}{c}0.008 \\
(0.008)\end{array}$ & $\begin{array}{c}0.008 \\
(0.008)\end{array}$ & $\begin{array}{c}0.008 \\
(0.008)\end{array}$ & $\begin{array}{c}0.008 \\
(0.008)\end{array}$ & $\begin{array}{c}0.008 \\
(0.008)\end{array}$ & $\begin{array}{c}0.008 \\
(0.008)\end{array}$ & $\begin{array}{c}0.008 \\
(0.008)\end{array}$ & $\begin{array}{c}0.008 \\
(0.008)\end{array}$ \\
\hline $\log (1+|\Delta \operatorname{CorpTax}|)$ & $\begin{array}{c}-0.453^{*} \\
(0.253)\end{array}$ & $\begin{array}{l}-0.453^{*} \\
(0.253)\end{array}$ & $\begin{array}{l}-0.440 * \\
(0.256)\end{array}$ & $\begin{array}{l}-0.454^{*} \\
(0.253)\end{array}$ & $\begin{array}{l}-0.453^{*} \\
(0.253)\end{array}$ & $\begin{array}{c}-0.453^{*} \\
(0.253)\end{array}$ & $\begin{array}{l}-0.453^{*} \\
(0.253)\end{array}$ & $\begin{array}{l}-0.442^{*} \\
(0.256)\end{array}$ \\
\hline $\log (1+|\Delta \operatorname{CorpTax}|) * A c q$ High Tax & $\begin{array}{c}0.417^{*} \\
(0.232)\end{array}$ & $\begin{array}{c}0.417 * \\
(0.232)\end{array}$ & $\begin{array}{c}0.413^{*} \\
(0.233)\end{array}$ & $\begin{array}{c}0.417^{*} \\
(0.232)\end{array}$ & $\begin{array}{c}0.417^{*} \\
(0.232)\end{array}$ & $\begin{array}{c}0.417^{*} \\
(0.232)\end{array}$ & $\begin{array}{c}0.417^{*} \\
(0.232)\end{array}$ & $\begin{array}{c}0.413^{*} \\
(0.233)\end{array}$ \\
\hline$B I T$ & $\begin{array}{c}-0.592^{* * *} \\
(0.062)\end{array}$ & $\begin{array}{c}-0.592^{* * *} \\
(0.062)\end{array}$ & $\begin{array}{c}-0.591^{* * *} \\
(0.062)\end{array}$ & $\begin{array}{c}-0.592^{* * *} \\
(0.062)\end{array}$ & $\begin{array}{c}-0.592^{* * *} \\
(0.062)\end{array}$ & $\begin{array}{c}-0.592^{* * *} \\
(0.062)\end{array}$ & $\begin{array}{c}-0.592^{* * *} \\
(0.062)\end{array}$ & $\begin{array}{c}-0.591^{* * *} \\
(0.062)\end{array}$ \\
\hline DTT & $\begin{array}{c}0.222^{* * *} \\
(0.059)\end{array}$ & $\begin{array}{c}0.222^{* * *} \\
(0.059)\end{array}$ & $\begin{array}{c}0.221^{* * *} \\
(0.060)\end{array}$ & $\begin{array}{c}0.222^{* * *} \\
(0.059)\end{array}$ & $\begin{array}{c}0.221^{* * *} \\
(0.059)\end{array}$ & $\begin{array}{c}0.222^{* * *} \\
(0.059)\end{array}$ & $\begin{array}{c}0.222^{* * *} \\
(0.059)\end{array}$ & $\begin{array}{c}0.221^{* * *} \\
(0.060)\end{array}$ \\
\hline Domestic & $\begin{array}{c}1.726^{* * *} \\
(0.071)\end{array}$ & $\begin{array}{c}1.726^{* * *} \\
(0.071)\end{array}$ & $\begin{array}{c}1.722^{* * *} \\
(0.071)\end{array}$ & $\begin{array}{c}1.724^{* * *} \\
(0.072)\end{array}$ & $\begin{array}{c}1.726^{* * *} \\
(0.071)\end{array}$ & $\begin{array}{c}1.726^{* * *} \\
(0.071)\end{array}$ & $\begin{array}{c}1.726^{* * *} \\
(0.071)\end{array}$ & $\begin{array}{c}1.717^{* * *} \\
(0.072)\end{array}$ \\
\hline Constant & $\begin{array}{c}-9.139 * * * \\
(0.621)\end{array}$ & $\begin{array}{c}-9.383^{* * *} \\
(0.722)\end{array}$ & $\begin{array}{c}-9.520^{* * *} \\
(0.691)\end{array}$ & $\begin{array}{c}-9.162^{* * *} \\
(0.624)\end{array}$ & $\begin{array}{c}-9.154 * * * \\
(0.623)\end{array}$ & $\begin{array}{c}-9.164^{* * *} \\
(0.624)\end{array}$ & $\begin{array}{c}-9.220^{* * *} \\
(0.634)\end{array}$ & $\begin{array}{c}-9.462^{* * *} \\
(0.698)\end{array}$ \\
\hline Industry Fixed Effects & Yes & No & Yes & Yes & Yes & Yes & Yes & Yes \\
\hline
\end{tabular}


Target Country Fixed Effects

Acquirer Country Fixed Effects

Year Effects

Observations

R-squared

F-test for Monitoring Interactions

(p-value of F-test)

$\begin{array}{cccccccc}\text { Yes } & \text { Yes } & \text { Yes } & \text { Yes } & \text { Yes } & \text { Yes } & \text { Yes } & \text { Yes } \\ \text { Yes } & \text { Yes } & \text { Yes } & \text { Yes } & \text { Yes } & \text { Yes } & \text { Yes } & \text { Yes } \\ \text { Yes } & \text { Yes } & \text { Yes } & \text { Yes } & \text { Yes } & \text { Yes } & \text { Yes } & \text { Yes } \\ & & & & & & & \\ 812,464 & 812,464 & 812,464 & 812,464 & 812,464 & 812,464 & 812,464 & 812,464 \\ 0.843 & 0.235 & 0.847 & 0.841 & 0.842 & 0.841 & 0.843 & 0.846 \\ & & & & & & & 21.95 \\ & & & & & & & 0.001)\end{array}$

Notes: Coefficient estimates are from a Pseudo-Poisson Maximum Likelihood specification where the dependent variable is the number of merger and acquisitions in a 2-digit SIC industry between a bilateral pair from the Top 50 countries (as defined in Appendix A) every five-year period between 1985 and 2014. A description and sources for our independent variables are reported in Appendix B.

Standard errors, clustered at the 2-digit SIC level, are in parentheses below each coefficient estimate. We denote coefficients that have a p-value less than $0.01,0.05$, and 0.10 with ${ }^{* * *}, * *$, and $*$, respectively. 
Table 6: Pseudo-Poisson Maximum Likelihood Estimates of the Determinants of Cross-Border M\&A - OECD only

\begin{tabular}{|c|c|c|c|c|c|c|c|c|}
\hline Independent Variables & (1) & $(2)$ & (3) & (4) & (5) & (6) & (7) & (8) \\
\hline Dist & $\begin{array}{c}-0.694^{* * *} \\
(0.038)\end{array}$ & $\begin{array}{c}-0.694^{* * *} \\
(0.038)\end{array}$ & $\begin{array}{c}-0.627^{* * *} \\
(0.048)\end{array}$ & $\begin{array}{c}-0.694^{* * *} \\
(0.038)\end{array}$ & $\begin{array}{c}-0.694^{* * *} \\
(0.038)\end{array}$ & $\begin{array}{c}-0.694^{* * *} \\
(0.038)\end{array}$ & $\begin{array}{c}-0.693^{* * *} \\
(0.038)\end{array}$ & $\begin{array}{c}-0.643^{* * *} \\
(0.050)\end{array}$ \\
\hline LangDist & $\begin{array}{c}-0.936^{* * *} \\
(0.064)\end{array}$ & $\begin{array}{c}-0.936^{* * *} \\
(0.064)\end{array}$ & $\begin{array}{c}-0.934^{* * *} \\
(0.065)\end{array}$ & $\begin{array}{c}-0.734^{* * *} \\
(0.114)\end{array}$ & $\begin{array}{c}-0.933^{* * *} \\
(0.065)\end{array}$ & $\begin{array}{c}-0.936^{* * *} \\
(0.064)\end{array}$ & $\begin{array}{c}-0.936^{* * *} \\
(0.064)\end{array}$ & $\begin{array}{c}-0.917^{* * *} \\
(0.150)\end{array}$ \\
\hline CultDist & $\begin{array}{c}-0.077^{* * *} \\
(0.013)\end{array}$ & $\begin{array}{c}-0.077^{* * *} \\
(0.013)\end{array}$ & $\begin{array}{c}-0.077^{* * *} \\
(0.013)\end{array}$ & $\begin{array}{c}-0.077^{* * *} \\
(0.013)\end{array}$ & $\begin{array}{c}0.003 \\
(0.036)\end{array}$ & $\begin{array}{c}-0.077^{* * *} \\
(0.013)\end{array}$ & $\begin{array}{c}-0.077^{* * *} \\
(0.013)\end{array}$ & $\begin{array}{c}-0.074^{* * *} \\
(0.020)\end{array}$ \\
\hline NoColony & $\begin{array}{c}-0.406^{* * *} \\
(0.033)\end{array}$ & $\begin{array}{c}-0.406^{* * *} \\
(0.033)\end{array}$ & $\begin{array}{c}-0.408^{* * *} \\
(0.034)\end{array}$ & $\begin{array}{c}-0.406^{* * *} \\
(0.033)\end{array}$ & $\begin{array}{c}-0.407^{* * *} \\
(0.033)\end{array}$ & $\begin{array}{c}-0.218^{* * *} \\
(0.082)\end{array}$ & $\begin{array}{c}-0.406^{* * *} \\
(0.033)\end{array}$ & $\begin{array}{c}-0.314^{* * *} \\
(0.047)\end{array}$ \\
\hline ReligDist & $\begin{array}{c}-1.433^{* * *} \\
(0.093)\end{array}$ & $\begin{array}{c}-1.433^{* * *} \\
(0.093)\end{array}$ & $\begin{array}{c}-1.434^{* * *} \\
(0.093)\end{array}$ & $\begin{array}{c}-1.433^{* * *} \\
(0.093)\end{array}$ & $\begin{array}{c}-1.434^{* * *} \\
(0.092)\end{array}$ & $\begin{array}{c}-1.433^{* * *} \\
(0.093)\end{array}$ & $\begin{array}{c}-1.177^{* * *} \\
(0.186)\end{array}$ & $\begin{array}{c}-1.380^{* * *} \\
(0.162)\end{array}$ \\
\hline Monitoring Importance (M) & & $\begin{array}{c}0.422 \\
(2.118)\end{array}$ & & & & & & \\
\hline Mx Dist & & & $\begin{array}{c}-1.091^{* *} \\
(0.448)\end{array}$ & & & & & $\begin{array}{c}-0.826 \\
(0.566)\end{array}$ \\
\hline Mx LangDist & & & & $\begin{array}{c}-3.369 * * \\
(1.408)\end{array}$ & & & & $\begin{array}{c}-0.282 \\
(2.151)\end{array}$ \\
\hline Mx CultDist & & & & & $\begin{array}{c}-1.369 * * \\
(0.622)\end{array}$ & & & $\begin{array}{c}-0.053 \\
(0.267)\end{array}$ \\
\hline Mx NoColony & & & & & & $\begin{array}{c}-3.085^{* * *} \\
(1.191)\end{array}$ & & $\begin{array}{l}-1.608^{*} \\
(0.832)\end{array}$ \\
\hline M $\times$ ReligDist & & & & & & & $\begin{array}{c}-4.077 \\
(2.854)\end{array}$ & $\begin{array}{c}-0.918 \\
(2.417)\end{array}$ \\
\hline Contig & $\begin{array}{c}0.070^{*} \\
(0.042)\end{array}$ & $\begin{array}{c}0.070^{*} \\
(0.042)\end{array}$ & $\begin{array}{c}0.070 \\
(0.042)\end{array}$ & $\begin{array}{c}0.070^{*} \\
(0.042)\end{array}$ & $\begin{array}{c}0.070 * \\
(0.042)\end{array}$ & $\begin{array}{c}0.070^{*} \\
(0.042)\end{array}$ & $\begin{array}{c}0.070 * \\
(0.042)\end{array}$ & $\begin{array}{c}0.069 \\
(0.042)\end{array}$ \\
\hline
\end{tabular}




\begin{tabular}{|c|c|c|c|c|c|c|c|c|}
\hline ComCurr & $\begin{array}{c}-0.108^{* * *} \\
(0.035)\end{array}$ & $\begin{array}{c}-0.108^{* * *} \\
(0.035)\end{array}$ & $\begin{array}{c}-0.107^{* * *} \\
(0.036)\end{array}$ & $\begin{array}{c}-0.109 * * * \\
(0.035)\end{array}$ & $\begin{array}{c}-0.108^{* * *} \\
(0.036)\end{array}$ & $\begin{array}{c}-0.108^{* * *} \\
(0.035)\end{array}$ & $\begin{array}{c}-0.108^{* * *} \\
(0.035)\end{array}$ & $\begin{array}{c}-0.106^{* * *} \\
(0.036)\end{array}$ \\
\hline ComLegal & $\begin{array}{c}0.013 \\
(0.034)\end{array}$ & $\begin{array}{c}0.013 \\
(0.034)\end{array}$ & $\begin{array}{c}0.013 \\
(0.034)\end{array}$ & $\begin{array}{c}0.013 \\
(0.034)\end{array}$ & $\begin{array}{c}0.011 \\
(0.034)\end{array}$ & $\begin{array}{c}0.013 \\
(0.034)\end{array}$ & $\begin{array}{c}0.013 \\
(0.034)\end{array}$ & $\begin{array}{c}0.013 \\
(0.034)\end{array}$ \\
\hline WTOFTA & $\begin{array}{c}0.030 \\
(0.079)\end{array}$ & $\begin{array}{c}0.030 \\
(0.079)\end{array}$ & $\begin{array}{c}0.034 \\
(0.080)\end{array}$ & $\begin{array}{c}0.029 \\
(0.079)\end{array}$ & $\begin{array}{c}0.029 \\
(0.079)\end{array}$ & $\begin{array}{c}0.030 \\
(0.079)\end{array}$ & $\begin{array}{c}0.030 \\
(0.079)\end{array}$ & $\begin{array}{c}0.035 \\
(0.080)\end{array}$ \\
\hline Log GDP acquirer & $\begin{array}{c}0.411^{*} \\
(0.216)\end{array}$ & $\begin{array}{c}0.411^{*} \\
(0.216)\end{array}$ & $\begin{array}{c}0.412^{*} \\
(0.216)\end{array}$ & $\begin{array}{c}0.411^{*} \\
(0.216)\end{array}$ & $\begin{array}{c}0.411^{*} \\
(0.216)\end{array}$ & $\begin{array}{c}0.411^{*} \\
(0.216)\end{array}$ & $\begin{array}{c}0.411^{*} \\
(0.216)\end{array}$ & $\begin{array}{c}0.412^{*} \\
(0.216)\end{array}$ \\
\hline Log GDP target & $\begin{array}{c}-0.243 \\
(0.307)\end{array}$ & $\begin{array}{c}-0.243 \\
(0.307)\end{array}$ & $\begin{array}{c}-0.245 \\
(0.307)\end{array}$ & $\begin{array}{c}-0.243 \\
(0.307)\end{array}$ & $\begin{array}{c}-0.243 \\
(0.307)\end{array}$ & $\begin{array}{c}-0.243 \\
(0.307)\end{array}$ & $\begin{array}{c}-0.244 \\
(0.307)\end{array}$ & $\begin{array}{c}-0.245 \\
(0.307)\end{array}$ \\
\hline$\triangle \log p c G D P[$ Tar-Acq] & $\begin{array}{c}-0.048 \\
(0.274)\end{array}$ & $\begin{array}{c}-0.048 \\
(0.274)\end{array}$ & $\begin{array}{c}-0.047 \\
(0.274)\end{array}$ & $\begin{array}{c}-0.048 \\
(0.274)\end{array}$ & $\begin{array}{l}-0.048 \\
(0.274)\end{array}$ & $\begin{array}{c}-0.048 \\
(0.274)\end{array}$ & $\begin{array}{c}-0.047 \\
(0.274)\end{array}$ & $\begin{array}{c}-0.046 \\
(0.274)\end{array}$ \\
\hline$(\triangle \log p c G D P)^{\wedge} 2$ & $\begin{array}{c}-0.278^{* * *} \\
(0.047)\end{array}$ & $\begin{array}{c}-0.278^{* * *} \\
(0.047)\end{array}$ & $\begin{array}{c}-0.278^{* * *} \\
(0.047)\end{array}$ & $\begin{array}{c}-0.278^{* * *} \\
(0.047)\end{array}$ & $\begin{array}{c}-0.278^{* * *} \\
(0.047)\end{array}$ & $\begin{array}{c}-0.278^{* * *} \\
(0.047)\end{array}$ & $\begin{array}{c}-0.278^{* * *} \\
(0.047)\end{array}$ & $\begin{array}{c}-0.278^{* * *} \\
(0.047)\end{array}$ \\
\hline $\log (1+|\Delta \operatorname{CorpTax}|)$ & $\begin{array}{c}-0.687^{* *} \\
(0.312)\end{array}$ & $\begin{array}{c}-0.687^{* *} \\
(0.312)\end{array}$ & $\begin{array}{c}-0.678^{* *} \\
(0.315)\end{array}$ & $\begin{array}{c}-0.688^{* *} \\
(0.312)\end{array}$ & $\begin{array}{c}-0.688^{* *} \\
(0.312)\end{array}$ & $\begin{array}{c}-0.687^{* *} \\
(0.312)\end{array}$ & $\begin{array}{c}-0.687^{* *} \\
(0.312)\end{array}$ & $\begin{array}{c}-0.678^{* *} \\
(0.315)\end{array}$ \\
\hline $\log (1+|\Delta \operatorname{CorpTax}|) *$ Acq High & & & & & & & & \\
\hline Tax & $\begin{array}{c}0.735^{* * *} \\
(0.281)\end{array}$ & $\begin{array}{c}0.735^{* * *} \\
(0.281)\end{array}$ & $\begin{array}{c}0.732^{* * *} \\
(0.282)\end{array}$ & $\begin{array}{c}0.735^{* * *} \\
(0.281)\end{array}$ & $\begin{array}{c}0.735^{* * *} \\
(0.281)\end{array}$ & $\begin{array}{c}0.735^{* * *} \\
(0.281)\end{array}$ & $\begin{array}{c}0.735^{* * *} \\
(0.282)\end{array}$ & $\begin{array}{c}0.732^{* * *} \\
(0.282)\end{array}$ \\
\hline BIT & $\begin{array}{c}-0.537^{* * *} \\
(0.054)\end{array}$ & $\begin{array}{c}-0.537^{* * *} \\
(0.054)\end{array}$ & $\begin{array}{c}-0.537^{* * *} \\
(0.054)\end{array}$ & $\begin{array}{c}-0.537^{* * *} \\
(0.054)\end{array}$ & $\begin{array}{c}-0.537^{* * *} \\
(0.054)\end{array}$ & $\begin{array}{c}-0.537^{* * *} \\
(0.054)\end{array}$ & $\begin{array}{c}-0.537^{* * *} \\
(0.054)\end{array}$ & $\begin{array}{c}-0.537^{* * *} \\
(0.054)\end{array}$ \\
\hline$D T T$ & $\begin{array}{c}0.881^{* * *} \\
(0.078)\end{array}$ & $\begin{array}{c}0.881^{* * *} \\
(0.078)\end{array}$ & $\begin{array}{c}0.881^{* * *} \\
(0.078)\end{array}$ & $\begin{array}{c}0.881^{* * *} \\
(0.078)\end{array}$ & $\begin{array}{c}0.881^{* * *} \\
(0.078)\end{array}$ & $\begin{array}{c}0.881^{* * *} \\
(0.078)\end{array}$ & $\begin{array}{c}0.881^{* * *} \\
(0.078)\end{array}$ & $\begin{array}{c}0.881^{* * *} \\
(0.078)\end{array}$ \\
\hline Domestic & $\begin{array}{c}1.487^{* * *} \\
(0.088)\end{array}$ & $\begin{array}{c}1.487^{* * *} \\
(0.088)\end{array}$ & $\begin{array}{c}1.484^{* * *} \\
(0.087)\end{array}$ & $\begin{array}{c}1.484^{* * *} \\
(0.087)\end{array}$ & $\begin{array}{c}1.486^{* * *} \\
(0.088)\end{array}$ & $\begin{array}{c}1.487^{* * *} \\
(0.088)\end{array}$ & $\begin{array}{c}1.486^{* * *} \\
(0.087)\end{array}$ & $\begin{array}{c}1.479 * * * \\
(0.087)\end{array}$ \\
\hline Constant & $\begin{array}{c}7.496^{* * *} \\
(1.990)\end{array}$ & $\begin{array}{c}7.333^{* * *} \\
(2.083)\end{array}$ & $\begin{array}{c}7.198^{* * *} \\
(2.012)\end{array}$ & $\begin{array}{c}7.478^{* * *} \\
(1.991)\end{array}$ & $\begin{array}{c}7.487^{* * *} \\
(1.991)\end{array}$ & $\begin{array}{c}7.475^{* * *} \\
(1.992)\end{array}$ & $\begin{array}{c}7.368^{* * *} \\
(2.011)\end{array}$ & $\begin{array}{c}7.240^{* * *} \\
(2.022)\end{array}$ \\
\hline
\end{tabular}


Industry Fixed Effects

Target Country Fixed Effects

Acquirer Country Fixed Effects

Year Effects

Observations

R-squared

F-test for Monitoring Interactions

(p-value of F-test) Notes: Coefficient estimates are from a Pseudo-Poisson Maximum Likelihood specification where the dependent variable is the number
of merger and acquisitions in a 2-digit SIC industry between a bilateral pair from the Top 50 countries (as defined in Appendix A) every five-year period between 1985 and 2014. A description and sources for our independent variables are reported in Appendix B. Standard errors, clustered at the 2-digit SIC level, are in parentheses below each coefficient estimate. We denote coefficients that have a p-value less than $0.01,0.05$, and 0.10 with $^{* * *}, * *$, and ${ }^{*}$, respectively. 
Table 7: Marginal Effect of Monitoring Costs on Cross-border M\&A Activity and Robustness of the Effect

\begin{tabular}{|c|c|c|c|c|c|c|c|c|c|}
\hline & $\begin{array}{c}\text { Full } \\
\text { Sample } \\
\end{array}$ & OECD & $\begin{array}{l}\text { Non- } \\
\text { OECD } \\
\end{array}$ & $\begin{array}{l}1985- \\
1999 \\
\end{array}$ & $\begin{array}{l}2000- \\
2014 \\
\end{array}$ & $\begin{array}{c}\text { Eliminate } \\
\text { domestic } \\
\text { M\&As } \\
\end{array}$ & $\begin{array}{c}\text { Separate } \\
\text { O*NET } \\
\text { Categories } \\
\end{array}$ & $\begin{array}{c}\text { Principal } \\
\text { components } \\
\end{array}$ & $\begin{array}{c}\text { O*NET } \\
\text { Monitoring } \\
\text { Skill } \\
\end{array}$ \\
\hline $\begin{array}{l}\text { F-Test for Joint Significance } \\
\text { of Monitoring Interactions } \\
\text { (p-value) }\end{array}$ & $\begin{array}{c}21.95 \\
(0.000)\end{array}$ & $\begin{array}{c}19.57 \\
(0.002)\end{array}$ & $\begin{array}{c}49.15 \\
(0.000)\end{array}$ & $\begin{array}{c}15.94 \\
(0.007)\end{array}$ & $\begin{array}{c}23.10 \\
(0.000)\end{array}$ & $\begin{array}{c}25.39 \\
(0.000)\end{array}$ & $\begin{array}{c}21.20 \\
(0.001)\end{array}$ & $\begin{array}{c}22.76 \\
(0.000)\end{array}$ & $\begin{array}{c}22.64 \\
(0.000)\end{array}$ \\
\hline $\begin{array}{l}\text { Reduction in Cross-Border } \\
\text { M\&A Activity for a Standard } \\
\text { Deviation Increase in } \\
\text { Monitoring Importance }\end{array}$ & $41.9 \%$ & $36.5 \%$ & $51.4 \%$ & $38.7 \%$ & $43.0 \%$ & $41.6 \%$ & $42.4 \%$ & $27.0 \%$ & $39.3 \%$ \\
\hline $\begin{array}{l}\text { F-test } \\
\text { (p-value) }\end{array}$ & $\begin{array}{c}13.31 \\
(0.000)\end{array}$ & $\begin{array}{c}7.32 \\
(0.007)\end{array}$ & $\begin{array}{c}21.31 \\
(0.000)\end{array}$ & $\begin{array}{c}7.57 \\
(0.006)\end{array}$ & $\begin{array}{c}13.44 \\
(0.000)\end{array}$ & $\begin{array}{c}7.02 \\
(0.008)\end{array}$ & $\begin{array}{c}14.60 \\
(0.000)\end{array}$ & $\begin{array}{c}10.66 \\
(0.011)\end{array}$ & $\begin{array}{c}11.18 \\
(0.001)\end{array}$ \\
\hline $\begin{array}{l}\text { Share of Distance Term in the } \\
\text { Overall Reduction }\end{array}$ & $92.6 \%$ & $76.1 \%$ & $92.2 \%$ & $71.3 \%$ & $99.1 \%$ & $99.8 \%$ & $91.7 \%$ & $95.9 \%$ & $93.7 \%$ \\
\hline
\end{tabular}

Notes: Calculations from estimations using a Pseudo-Poisson Maximum Likelihood specification where the dependent variable is the number of merger and acquisitions in a 2-digit SIC industry between bilateral pairs of countries every 5-year period where the sample of countries and time period varies according to the column heading. Except for columns titled "OECD" and "non-OECD", the sample of countries includes all top 50 countries in the full sample. 
Table 8: The Effect of Monitoring Costs on Predicted Cross-Border M\&A by Sector

PANEL A: Full Sample

\begin{tabular}{|c|c|c|c|c|c|}
\hline & \multicolumn{2}{|c|}{$\begin{array}{l}\text { Predicted Value of the } \\
\text { Dependent Variable }\end{array}$} & & \multirow[b]{2}{*}{$\begin{array}{c}\text { F-test } \\
\text { statistical } \\
\text { significance } \\
\text { (p-value) } \\
\end{array}$} & \multirow[b]{2}{*}{ Observations } \\
\hline & $\begin{array}{c}\text { At Means of } \\
\text { Data } \\
\end{array}$ & $\begin{array}{l}\text { With the Same } \\
\text { Monitoring } \\
\text { Costs as } \\
\text { Manufacturing } \\
\end{array}$ & $\begin{array}{c}\text { Percent } \\
\text { Difference } \\
\end{array}$ & & \\
\hline Manufacturing & 0.0254 & 0.0254 & ---- & ---- & 238,960 \\
\hline Non-Manufacturing & 0.0165 & 0.0248 & $50.3 \%$ & $5.44(0.020)$ & 573,504 \\
\hline Mining & 0.0234 & 0.0211 & $-9.8 \%$ & $7.63(0.007)$ & 47,792 \\
\hline Construction & 0.0177 & 0.0184 & $4.0 \%$ & $6.96(0.008)$ & 35,844 \\
\hline $\begin{array}{l}\text { Transportation, communications, } \\
\text { and utilities }\end{array}$ & 0.0154 & 0.0161 & $4.5 \%$ & $6.96(0.008)$ & 107,532 \\
\hline Wholesale trade & 0.0548 & 0.1209 & $120.6 \%$ & $4.09(0.043)$ & 23,896 \\
\hline Retail trade & 0.0090 & 0.0293 & $225.6 \%$ & $3.17(0.075)$ & 95,584 \\
\hline Finance, insurance, and real estate & 0.0391 & 0.1032 & $163.9 \%$ & $3.62(0.057)$ & 83,636 \\
\hline Services & 0.0121 & 0.0136 & $12.4 \%$ & $6.61(0.010)$ & 179,220 \\
\hline
\end{tabular}




\begin{tabular}{|c|c|c|c|c|c|}
\hline \multirow[b]{2}{*}{ Sector } & \multicolumn{2}{|c|}{$\begin{array}{l}\text { Predicted Value of the } \\
\text { Dependent Variable }\end{array}$} & \multirow[b]{2}{*}{$\begin{array}{c}\text { Percent } \\
\text { Difference } \\
\end{array}$} & \multirow[b]{2}{*}{$\begin{array}{c}\text { F-test } \\
\text { statistical } \\
\text { significance } \\
\text { (p-value) } \\
\end{array}$} & \multirow[b]{2}{*}{ Observations } \\
\hline & $\begin{array}{c}\text { At Means of } \\
\text { Data } \\
\end{array}$ & $\begin{array}{c}\text { With the Same } \\
\text { Monitoring } \\
\text { Costs as } \\
\text { Manufacturing } \\
\end{array}$ & & & \\
\hline Manufacturing & 0.0489 & 0.0489 & ---- & ---- & 90,900 \\
\hline Non-Manufacturing & 0.0334 & 0.0472 & $41.3 \%$ & $3.29(0.070)$ & 218,160 \\
\hline Mining & 0.0406 & 0.0373 & $-8.1 \%$ & $4.63(0.031)$ & 18,180 \\
\hline Construction & 0.0334 & 0.0346 & $3.6 \%$ & $4.64(0.031)$ & 13,635 \\
\hline $\begin{array}{l}\text { Transportation, communications, } \\
\text { and utilities }\end{array}$ & 0.0292 & 0.0304 & $4.1 \%$ & $4.57(0.033)$ & 40,905 \\
\hline Wholesale trade & 0.1157 & 0.2256 & $95.0 \%$ & $2.46(0.117)$ & 9,090 \\
\hline Retail trade & 0.0200 & 0.0540 & $170.0 \%$ & $1.87(0.171)$ & 36,360 \\
\hline Finance, insurance, and real estate & 0.0777 & 0.1764 & $127.0 \%$ & $2.16(0.142)$ & 31,815 \\
\hline Services & 0.0258 & 0.0284 & $10.1 \%$ & $4.17(0.041)$ & 68,175 \\
\hline
\end{tabular}

Notes: The first column of data provides the predicted number of bilateral cross-border M\&As per 5-year period for 2-digit SIC codes connected with the listed sector at the means of all the regressors. Predictions are based on the estimates from column 8 of Table 5 for Panel A (full sample) and column 8 of Table 6 for Panel B (OECD-only sample). Column 2 provides the predicted value of the dependent variable when we modify the data so that the sector has the same level of monitoring importance (M) as manufacturing, keeping the level of all other variables in the regressor set at their means. Column 3 provides the percentage difference between columns 1 and 2 to show how much the predicted number of cross-border M\&As changes when we put the sector's monitoring importance the same as manufacturing, and column 4 provides the Ftest and associated p-value indicating the statistical significance of this difference. 


\section{Appendix A}

OECD Countries and Additional Countries Comprising the Top 50

Target Countries for Cross-border M\&A

\begin{tabular}{llll}
\hline \multicolumn{1}{c}{ OECD Countries } & \multicolumn{2}{c}{$\begin{array}{c}\text { Additional Top 50 } \\
\text { Target Countries }\end{array}$} \\
\hline \hline Australia & Luxembourg & Argentina & Malaysia \\
Austria & Mexico & Brazil & Peru \\
Belgium & Netherlands & Bulgaria & Philippines \\
Canada & New Zealand & Chile & Romania \\
Czech Republic & Norway & China & Russia \\
Denmark & Poland & Colombia & Singapore \\
Finland & Portugal & Hong Kong & South Africa \\
France & South Korea & Iceland & Taiwan \\
Germany & Spain & India & Thailand \\
Greece & Sweden & Indonesia & Ukraine \\
Hungary & Switzerland & Israel & Vietnam \\
Ireland & Turkey & & \\
Italy & United Kingdom & & \\
Japan & United States & & \\
\hline
\end{tabular}




\section{Appendix B \\ Variable Description and Sources}

\section{Dependent Variable}

\section{Merger and Acquistion (M\&A) Activity}

Count of M\&A transactions from one country (acquirer country) into another country (target country) in a 2-digit SIC sector during a five-year period starting with the 19851989 period through the 2010-2014 period. Thomson Reuters SDC SDC Platinum M\&A Database is the source for these data.

\section{Independent Variables}

\section{Monitoring Importance $(M)$}

The Occupational Information Network ( $\left.0^{*} \mathrm{NET}\right)$ developed by the U.S. Department of Labor provides information on the skills and abilities required in over 950 occupations within the U.S. economy. This can be accessed at the website:

https://www.onetonline.org.

For each occupation, experts assess and rank the relevance of 35 distinct skill categories (e.g., coordination, negotiation, active listening, etc.). We focus on skills for which the relevance of each skill is evaluated in two ways: 1) the "importance" of a skill in a given occupation is measured by a score from 1 (less important) to 5 (very important); and 2) the "level" of a skill required in a given occupation is measured by a score from 0 (minimum level) to 7 (highest proficiency level). The two scores need not be correlated, for example, when a particular skill such as speaking comprehension is very important in a particular occupation, however at a level that is not very advanced or very sophisticated.

We identify 13 skills that are potentially related to monitoring an affiilate in a foreign country and list them here with their $0^{*}$ NET description ${ }^{14}$ :

Monitoring skills:

a) Coordination - Adjusting actions in relation to others' actions.

b) Management of material resources - Obtaining and seeing to the appropriate use of equipment, facilities, and materials needed to do certain work.

c) Management of personnel - Motivating, developing, and directing people as they work, identifying the best people for the job.

\footnotetext{
${ }^{14}$ The full list of O*NET skills are at https://www.onetonline.org/find/descriptor/browse/Skills/.
} 
d) Monitoring - Monitoring/Assessing performance of yourself, other individuals, or organizations to make improvements or take corrective action

Cultural skills:

a) Negotiation - Bringing others together and trying to reconcile differences.

b) Persuasion - Persuading others to change their minds or behavior.

c) Service orientation - Actively looking for ways to help people.

d) Social perceptiveness - Being aware of others' reactions and understanding why they react as they do.

Language skills:

a) Active listening - Giving full attention to what other people are saying, taking time to understand the points being made, asking questions as appropriate, and not interrupting at inappropriate times.

b) Instructing - Teaching others how to do something.

c) Reading comprehension - Understanding written sentences and paragraphs in work related documents.

d) Speaking - Talking to others to convey information effectively.

e) Writing - Communicating effectively in writing as appropriate for the needs of the audience.

To construct an $0^{*}$ NET skill score for each of the 13 skills at the 2-digit SIC industry level, we implement the following steps:

1. For each skill level by occupation, we multiply the importance score by the level score to obtain a unique ranking value of that skill for that occupation. We then rescale the resulting score to take values between 0-1.

2. Occupations in $0^{*}$ NET database are recorded using SOC 8-digit classification for 2010. We average the unique $0^{*}$ NET occupation scores at the SOC 6-digit level and then use a crosswalk to convert the 2010 SOC codes to the corresponding 2000 SOC codes (using a crosswalk provided by the BLS:

https://www.bls.gov/soc/soc_2000_to_2010_crosswalk.xls).

3. We collected data from the Occupational Employment Statistics (OES) Survey provided by the BLS on employment by 2-digit SIC sectors across SOC occupation codes for year 2000 (https://www.bls.gov/oes/tables.htm) and then construct for each 2-digit SIC industry the employment share of all occupations related to Management (SOC 11), Business and Financial Operations (SOC 13), as well as Sales and Related occupations (SOC 41).

4. Using 2000 SOC codes as identifiers, we merge the $0^{*}$ NET occupation scores with the employment shares of managerial/business/sales occupations within each 2digit SIC industries.

5. Using the 2000 employment shares as weights, we aggregate the $0^{*}$ NET skill scores across the selected managerial/business/sales occupations to obtain average O*NET skill scores at SIC 2-digit level. 
As described in the text, our primary measure of monitoring importance takes the simple average of these $130^{*}$ NET skill scores.

\section{Geographic distance (Dist)}

This is a population-weighted bilateral distance measure that comes from the GeoDist database at CEPII (http://www.cepii.fr/CEPII/en/bdd_modele/presentation.asp?id=6). A benefit of using CEPII data is that it provides information on internal distances for our observations where the acquirer and target countries are the same (i.e., domestic M\&A)

\section{Language distance (LangDist)}

We begin with a measure of common native languages between countries that is a continuous variable between 0 and 1 measuring the percentage of people from each country that share a common native language. This was developed by Melitz and Toubal, 2014, and is available as part of the Language database at CEPII: http://www.cepii.fr/CEPII/en/bdd modele/presentation.asp?id=19. We construct our language distance variable as 1 minus the common native language value.

\section{Cultural distance (CultDist)}

As described in the text, we use Kogut and Singh's (1988) approach to constructing this variable which is a composite index formed based on the weighted difference between the four cultural dimensions (i.e. power distance, uncertainty avoidance, masculinity/femininity, and individualism) of each country. Algebraically, this composite index is constructed as follows:

$$
C D_{i j}=\sum_{c=1}^{4}\left\{\left(I_{c i}-I_{c j}\right)^{2} / V_{c}\right\} / 4,
$$

where $I_{c i}$ stands for the host country $i$ 's $c$ th cultural dimension, $I_{c j}$ is the home country $j$ 's $c$ th cultural dimension, $V_{c}$ is the variance of the $c$ th dimension, $C D_{i j}$ is the cultural distance index between the host country $i$ and home country $j$. The cultural dimensions needed to construct this index are taken from Geert Hofstede's website at http://www.geerthofstede.nl/dimension-data-matrix.

\section{No Former Colonial Relationship (NoColony)}

We define an indicator of colony that takes the value of 1 if either the target nation was a colony of the acquirer nation, or vice-versa. For each pair of countries, we construct 
an indicator for not having a former (or current) colonial relationship as 1 minus the colony variable.

\section{Religious distance (ReligDist)}

We use information from the CIA Factbook on the fraction of population in a country assigned to one of the following religions: Catholic, protestant, Muslim, Buddhist, Hindu, Orthodox or Jewish. (https://www.cia.gov/library/publications/the-world-factbook/). We construct a common religion index between two countries by summing the products of population shares with the same religion; this leads to a continuous index between 0 and 1 , and then define the religious distance variable as 1 minus the common religion index.

\section{Contiguity (Contig)}

An indicator variable for whether the two countries share a border. We source this variable from the CEPII Gravity database:

(http://www.cepii.fr/CEPII/en/bdd modele/presentation.asp?id=8)

\section{Common currency (ComCurr)}

An indicator variable for whether the two countries share a common currency. We source this variable from the CEPII Gravity database:

(http://www.cepii.fr/CEPII/en/bdd modele/presentation.asp?id=8)

\section{Common legal system (ComLegal)}

An indicator variable for whether the two countries share a common legal system. We source this variable from the CEPII Gravity database:

(http://www.cepii.fr/CEPII/en/bdd modele/presentation.asp?id=8)

\section{FTA participation (WTOFTA)}

An indicator variable for whether two countries have a bilateral free trade agreement with each other based on information available from the WTO. We source this variable from the CEPII Gravity database:

(http://www.cepii.fr/CEPII/en/bdd modele/presentation.asp?id=8)

11.GDP and per-capita GDP terms (Log GDP Acquirer, Log GDP Target, $\triangle$ Log pcGDP [Tar-Acq], and ( $\left.\triangle \log P c G D P)^{\wedge} 2\right)$ 
GDP and population data come from World Bank's World Development Indicators (WDI) database: https://datacatalog.worldbank.org/dataset/world-developmentindicators. In the few instances where either population or GDP data were missing, we used linear interpolations to fill in the missing values. We then constructed 5-year logged average values of GDP and GDP per capita. $\triangle$ Log pcGDP [Tar-Acq] is constructed as the difference in the per-capita GDP of the target country and the per-capita GDP of the acquirer country, and $(\triangle \log p c G D P)^{\wedge} 2$ is the square of $\Delta \log p c G D P$ [Tar-Acq].

\section{Corporate tax rate differentials and its interaction with a "high tax" indicator variable $(\log (1+|\Delta \operatorname{CorpTax}|)$ and $\log (1+|\Delta \operatorname{CorpTax}|) * A c q$ High Tax $)$} We get information on the statutory corporate tax rate from two sources. The first is the World Tax Database provided by the Office of Tax Policy Research at the University of Michigan: https://www.bus.umich.edu/otpr/otpr/default.asp. This contains tax rate information for a large set of countries spanning the period from 1985 to 2002. Our second data source, KPMG provides more recent statutory tax rate information covering the period from 2003 to 2014 and is available at: https://home.kpmg/mm/en/home/services/tax/tax-tools-and-resources/tax-ratesonline/corporate-tax-rates-table.html.

We combine the two data sources and limit the country sample to the top 50 FDI countries. For each country pair, we then construct the tax rate differential as the natural log of 1 plus the absolute difference in corporate tax rates. In this way, two countries with the same tax rates will have a tax differential of zero. We also construct an indicator variable equal to 1 if the acquirer nation is the country with the higher tax rate within a given pair of countries, and interact it with the tax rate differential variable. This interaction term can capture any differences in cross-border M\&A activity driven by high tax acquirers looking to buy foreign affiliates in low tax jurisdictions.

\section{Bilateral investment treaty (BIT)}

We collected information on bilateral investment treaties (BITs) from the United Nation's Conference on Trade and Development (UNCTAD): https://investmentpolicyhub.unctad.org/IIA. We construct an indicator variable for whether the bilateral pair of countries had a BIT "in force" during any year of the associated five-year interval.

\section{Double taxation treaty (DTT)}

Data were drawn from International Bureau of Fiscal Documentation (IBFD) website (https://www.ibfd.org) at their treaty look-up page:

https: //online.ibfd.org/kbase/\#topic $=\mathrm{d} \& \mathrm{~N}=3+10+5302+4932 \&$ ownSubscription=false $\underline{\& N e}=4912 \& N u=$ global rollup key $\& \mathrm{~Np}=2 \&$ colid $=4932 \& N s=$ sort country one $\% 7 \mathrm{C} 0 \% 7 \mathrm{C}$ 
\%7Csort country two\%7C0\%7C\%7Csort organization one\%7C0\%7C\%7Cibfd-tttitle\%7C0\%7C\%7Cibfd-tt-signdate-s\%7C0\&rpp=25\&WT.i s type=Navigation

We used the following criteria to determine a year for the presence of a double taxation treaty between two countries:

1) Only sampled treaties involving agreements about taxation of income and/or capital. 2) Used the latest of "Effective" or "Signed" date, provided both have occurred.

We then construct the variable to take the value of " 1 " if a signed and effective treaty is present between the acquirer and target country at any time during the associated fiveyear interval. 